\title{
THE MOLECULAR BASIS OF THE ANTICANCER PROPERTIES OF QUERCETIN
}

\author{
S. Adorisio', M. P. Argentieri², P. Avato², G. Caderni ${ }^{3}$, S. Chioccioli ${ }^{3}$, S. Cirmi ${ }^{2}$, \\ D. V. Delfino ${ }^{1}$, G. Greco ${ }^{4}$, P. Hrelia ${ }^{5}$, M. Iriti ${ }^{6}$, M. Lenzi $^{5}$, G. E. Lombardo7, C. Luceri ${ }^{3}$, \\ A. Maugeri ${ }^{7}$, M. Montopoli ${ }^{8}$, I. Muscari ${ }^{9}$, M. F. Nanì ${ }^{10}$, M. Navarra ${ }^{7}$, S. Gasperini ${ }^{5}$, \\ E. Turrini ${ }^{4}$, C. Fimognari ${ }^{4}$
}

${ }^{1}$ Foligno Nursing School, Department of Medicine, University of Perugia, Foligno, Perugia, Italy

${ }^{2}$ Department of Pharmacy-Drug Sciences, University of Bari Aldo Moro, Bari, Italy

${ }^{3}$ Department of NEUROFARBA, Section of Pharmacology and Toxicology, University of Florence, Florence, Italy

${ }^{4}$ Department for Life Quality Studies, University of Bologna, Bologna, Italy

${ }^{5}$ Department of Pharmacy and Biotechnologies, University of Bologna, Bologna, Italy

${ }^{6}$ Department of Agricultural and Environmental Sciences, Milan State University, Milan, Italy

${ }^{7}$ Department of Chemical, Biological, Pharmaceutical and Environmental Sciences, University of Messina,

Messina, Italy

${ }^{8}$ Department of Pharmaceutical and Pharmacological Sciences, University of Padova, Padua, Italy

${ }^{9}$ Department of Medicine, University of Perugia, Santa Maria Hospital, Terni, Italy

${ }^{10}$ Department of Pharmacy, University of Naples Federico II, Naples, Italy

All the authors belong to the Working Group "Pharmacognosy, Phytotherapy and Nutraceuticals" of the Italian Pharmacological Society, Milan, Italy

E-mail: carmela.fimognari@unibo.it

Doi: 10.36118/pharmadvances.2021.10

\section{SUMMARY}

Quercetin is a major constituent of various dietary products, which is increasingly being investigated as a therapeutic option in the oncological field. It has attracted extensive interest due to its ability of interacting with different molecular targets and evoking a broad spectrum of chemopreventive and anticancer activities. In this review, we have tried to present and critically discuss its potential against an extensive range of cancers including lung, ovarian, prostate, breast, colorectal, bladder cancers. We also highlighted studies that combined quercetin with standard anticancer drugs and delivered it via novel techniques and included a detailed description of its proposed mechanism(s) of action, and pharmacokinetic and safety profile.

\section{Key words}

Quercetin; cancer; bioavailability; mechanisms of action; in vivo studies; in vitro studies.

\section{Impact statement}

Quercetin exhibits a broad spectrum of anticancer activities such as pro-apoptotic, antiproliferative, antiangiogenic, and antimetastatic effects and blocks an extensive range of cancers including lung, ovarian, prostate, breast, colorectal, bladder cancers. 


\section{INTRODUCTION}

According to a 2021 report, cancer ranked as the first or second most common contributor to mortality across the world and a doubling of its incidence is predicted by 2070 relative to 2020 (1). Despite extensive knowledge on the molecular aspects of this disease, different modifications at molecular and genetic levels in cancer cells result in some difficulties to establish effective anticancer therapies and overcome drug resistance caused by cancer cells adapting to chemotherapy drugs. Chemicals occurring in vegetables, fruits, spices, grains, and other foods have been found to effectively improve the anticancer activity and protect against the side effects of conventional anticancer treatments. Quercetin $\left(3,3^{\prime}, 4^{\prime}, 5,7\right.$-pentahydroxyflavone) (figure 1) is a ubiquitous dietary bioflavonoid widely synthesized in the leaves, flowers, $f$ ruits, and seeds of a variety of food plants (2). In plants, the synthesis of this specialized metabolite proceeds via the combination of the shikimate and acetate metabolic pathways. Quercetin may occur in plant cells as free aglycone, but most frequently in the conjugated water-soluble glycosylated form giving rise to a high number of quercetin derivatives (3). Quercetin-3-O-glycosides with glucose, galactose, xylose or rhamnose are the most common products, as an example quercitrin (quercetin-3-O-rhamnoside) and rutin (quercetin-3-O-rhamnosyl $(1 \rightarrow 6)$ glucoside); the hydroxyl group at C7 represents another common O-glycosylation site in the molecule. Both the hydroxylic functions at $\mathrm{C} 3$ and $\mathrm{C} 7$ are often substituted at the same time, as an example in 3-O-rhamnoside-7-O-glucoside. Quercetin C-glycosides are instead relatively rare in plants. Glycosides of quercetin can, additionally, contain acyl substituents (3). Other frequently occurring derivatives of quercetin include the formation of ethers (mostly with methanol to give the corresponding methoxy derivatives) and may contain up to five ether groups in various configurations; these compounds can also have sugar substituents.

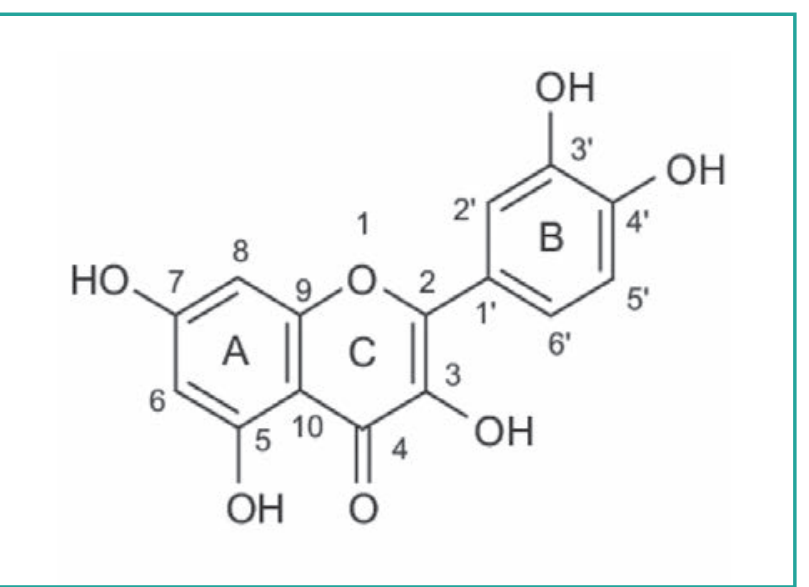

Figure 1. Chemical structure of quercetin.

Quercetin bounded forms with sulfate or alkyl residues are instead less present in plants (3). Quercetin has been proven to play a broad spectrum of anticancer activities such as pro-apoptotic, antiproliferative, antiangiogenic, and antimetastatic effects and blocks an extensive range of cancers including lung, ovarian, prostate, breast, colorectal, bladder cancers (4). In this review, we summarize and analyze the anticancer properties of quercetin on several systemic tumors in vivo and in vitro and its main cellular and molecular mechanisms. Quercetin's chemistry, pharmacokinetics and safety are also briefly reviewed.

\section{The basis of chemical structure}

Despite its polyhydroxylated nature, quercetin is a lipophilic compound scarcely soluble in water; its derivatives can instead have a lipophilic or hydrophilic character depending on the type and number of functional groups. Generally, glycosylation increases the hydrophilicity of the molecule, whereas quercetin methyl and alkyl derivatives are lipophilic. Low solubility of the aglycone in water is a major challenge for its therapeutic applications (3).

Quercetin polyhydroxylated nature also determines its bioactivity. The catechol-containing $B$ ring (figure 1), the 2,3-double bond in conjugation with the carbonyl function at $\mathrm{C} 4$ in the $\mathrm{C}$ ring and the hydroxyl substitu- 
ents at $\mathrm{C} 3$ and $\mathrm{C} 5$ positions are important reactive centers in the molecule. Quercetin gets easily oxidized and, primarily through the oxidation of its catechol group, can form a quite stable reactive free o-semiquinone radical acting as a reactive oxygen species (ROS)-scavenger. It can further undergo auto-oxidation and originate bioactive electrophilic tautomeric quinones that are able to bind to nucleophilic amino acid residues at active site of target enzymes. Moreover, the presence of the five hydroxyl groups enables quercetin to have chelating sites and form complexes with metal ions (especially copper and iron) thus inhibiting the metal-mediated generation of free oxidizing radicals (5). Quercetin is more active than its corresponding glycosides, while the flavonoid-metal complexes with a lower redox potential have a higher antioxidant potency than the free aglycone $(3,5)$.

\section{PHARMACOKINETICS AND BIOAVAILABILITY}

The chemical structure of the aglycone and the type and position of the sugar moiety are major determinants of absorption of quercetin, as well as the composition of the diet, with important consequences on pharmacokinetic parameters. For instance, dietary fat enhances the micellization of quercetin at the small intestine (table I) and increases its absorption and bioavailability (6).

Quercetin occurs in crystalline form at body temperatures and is relatively lipophilic with low water solubility, poor bioaccessibility, and low oral bioavailability (table I). For this reason, quercetin is often formulated as nanoparticles to improve its poor solubility and bioavailability. In the small intestine, quercetin aglycone passively diffuses from the intestinal lumen into the enterocytes where it is either directly absorbed (via passive diffusion) or metabolized before absorption (via active transport) into the hepatic portal vein (figure 2). Differently from the aglycone, glycosides can be transported into the enterocytes by the sodium-glucose cotransporter (SGLUT1, with a higher affinity for quercetin glucosides than other glycosides), and then deglycosylated by cytosolic hydrolases (figure 2). Moreover, quercetin glycosides are substrate for lactase phlorizin hydrolase ( $\mathrm{LPH}$, a family of $\beta$-glucosidases), a luminal brush border enzyme that catalyzes the deglycosylation and enables the aglycone to pass through enterocyte membranes via passive diffusion (figure 2). Again, the absorbed aglycone and its metabolites are transported passively or actively, respectively, into the hepatic portal vein. The absorbed aglycone bound to serum albumin and the metabolites are transported to the liver, where the aglycone is further metabolized (figure 2). Metabolism involves phase I and phase II reactions in enterocytes and hepatocytes to produce water-soluble derivatives (methyl, glucuronide, and sulfate conjugates), which are ultimately transported into the systemic circulation for distribution to target tissues (figure 2). The high levels of quercetin-conjugated metabolites detected in the bile indicate enterohepatic recirculation (figure 2). Indeed, some metabolites are excreted into the small intestine through this route and reabsorbed as aglycones after deconjugation catalyzed by bacterial $\beta$-glucuronidase and sulfatase. Noteworthy, after enterocyte absorption, quercetin, its glycosides and their metabolites can be effluxed back into the intestinal lumen by the multidrug resistance-associated pumps (7).

Finally, quercetin glycosides not absorbed in the small intestine reach the large intestine where they are fermented by the colonic microbiota (Bacteroides fragilis, Eubacterium ramulus, Clostridium perfringens, Bacteroides JY-6, Bifidobacterium B-9, Lactobacillus L-2, and Streptococcus S-2), which degrades quercetin aglycone into other phenolic compounds (mainly homoprocatechuic acid, protocatechuic acid and 4-hydroxybenzoic acid) by ring cleavage at the heterocyclic $\mathrm{C}$-ring (figure 2) (8). 
Table I. Intervention studies on quercetin pharmacokinetics involving healthy subjects consuming food sources of quercetin or treated with quercetin as pure compound.

\begin{tabular}{|c|c|c|c|c|}
\hline $\begin{array}{l}\text { Food source/aglycone/ } \\
\text { glycoside }\end{array}$ & Quercetin dose & $\begin{array}{l}\text { Plasma } \\
\text { pharmacokinetics }\end{array}$ & $\begin{array}{l}\text { Urinary } \\
\text { excretion/ } \\
\text { concentration }\end{array}$ & Reference \\
\hline $\begin{array}{l}\text { Black tea (1600 mL/day) } \\
\text { Onions (129 g/day) }\end{array}$ & $\begin{array}{l}49 \mathrm{mg} \text { (glycosides) } \\
13 \mathrm{mg} \text { (glycosides) }\end{array}$ & $\begin{array}{l}\text { NM } \\
\text { NM }\end{array}$ & $\begin{array}{l}0.5 \% \\
1.1 \%\end{array}$ & $(123)$ \\
\hline $\begin{array}{l}\text { Black tea ( } 375 \mathrm{~mL} / \text { day) } \\
\text { Onions ( } 50 \mathrm{~g} / \text { day) } \\
\text { Red wine ( } 750 \mathrm{~mL} / \text { day) }\end{array}$ & $\begin{array}{l}13.7 \mathrm{mg} \\
15.9 \mathrm{mg} \\
14.2 \mathrm{mg} \\
\end{array}$ & $\begin{array}{l}C_{\max }=0.026 \mu \mathrm{M} \\
C_{\max }=0.053 \mu \mathrm{M} \\
C_{\text {max }}=0.026 \mu \mathrm{M}\end{array}$ & $\begin{array}{l}0.252 \mu \mathrm{M} \\
0.509 \mu \mathrm{M} \\
0.371 \mu \mathrm{M}\end{array}$ & (124) \\
\hline Onions (NR) & $68 \mathrm{mg}$ & $\begin{array}{l}\mathrm{C}_{\max }=0.74 \mu \mathrm{M} \\
\mathrm{T}_{\max }=0.7 \pm 1.1 \mathrm{~h} \\
\mathrm{~T}_{1 / 2}=28 \pm 92 \mathrm{~h} \\
\mathrm{AUCC}_{(0-36 \mathrm{~h})}=7.71 \mu \mathrm{M} \mathrm{h}\end{array}$ & $1.39 \%$ & (125) \\
\hline Apple sauce + peel (NR) & $98 \mathrm{mg}$ & $\begin{array}{l}\mathrm{C}_{\max }=0.30 \mu \mathrm{M} \\
\mathrm{T}_{\max }=2.5 \pm 0.7 \mathrm{~h} \\
\mathrm{~T}_{1 / 2}=23 \pm 32 \mathrm{~h} \\
\mathrm{AUC}_{(0-36 \mathrm{~h})}=3.5 \mu \mathrm{M} \mathrm{h}\end{array}$ & $0.44 \%$ & \\
\hline Rutin & $100 \mathrm{mg}$ & $\begin{array}{l}\mathrm{C}_{\max }=0.30 \mu \mathrm{M} \\
\mathrm{T}_{\max }=9.3 \pm 1.8 \mathrm{~h} \\
\mathrm{~T}_{1 / 2}=\mathrm{ND} \\
\mathrm{AUCC}_{(0-36 \mathrm{~h})}=3.3 \mu \mathrm{Mh}\end{array}$ & $0.35 \%$ & \\
\hline Onions (160 g) & $100 \mathrm{mg}$ & $\begin{array}{l}C_{\max }=2.31 \mu \mathrm{M} \\
\mathrm{T}_{\max }=0.68 \pm 0.22 \mathrm{~h} \\
\mathrm{~T}_{1 / 2}=10.9 \pm 4.1 \mathrm{~h} \\
\mathrm{AUC}_{(0-24 \mathrm{~h})}=32.1 \mu \mathrm{M} \mathrm{h}\end{array}$ & $6.4 \%$ & (126) \\
\hline Quercetin-4'-O-glucoside & $100 \mathrm{mg}$ & $\begin{array}{l}\mathrm{C}_{\max }=2.12 \mu \mathrm{M} \\
\mathrm{T}_{\max }=0.70 \pm 0.31 \mathrm{~h} \\
\mathrm{~T}_{1 / 2}=11.9 \pm 4.0 \mathrm{~h} \\
\mathrm{AUC}_{(0-24 \mathrm{~h})}=27.8 \mu \mathrm{M} \mathrm{h}\end{array}$ & $4.5 \%$ & \\
\hline Buckwheat tea (NR) & $200 \mathrm{mg}$ & $\begin{array}{l}\mathrm{C}_{\max }=0.64 \mu \mathrm{M} \\
\mathrm{T}_{\max }=4.32 \pm 1.83 \mathrm{~h} \\
\mathrm{~T}_{1 / 2}=10.3 \pm 3.5 \mathrm{~h} \\
\mathrm{AUUC}_{(0-36 \mathrm{~h})}=12.6 \mu \mathrm{M} \mathrm{h}\end{array}$ & $1.0 \%$ & \\
\hline Rutin & $200 \mathrm{mg}$ & $\begin{array}{l}\mathrm{C}_{\max }=0.32 \mu \mathrm{M} \\
\mathrm{T}_{\max }=6.98 \pm 2.94 \mathrm{~h} \\
\mathrm{~T}_{1 / 2}=11.8 \pm 3.1 \mathrm{~h} \\
\mathrm{AUCC}_{(0-36 \mathrm{~h})}=8.3 \mu \mathrm{M} \mathrm{h}\end{array}$ & $0.90 \%$ & \\
\hline $\begin{array}{l}\text { Onions }(100 \mathrm{~g}) \\
\text { Aglycone }\end{array}$ & $\begin{array}{l}47 \mathrm{mg} \\
544 \mathrm{mg}\end{array}$ & $\begin{array}{l}\text { NM } \\
\text { NM }\end{array}$ & $\begin{array}{l}1.17 \mu \mathrm{M} \\
1.69 \mu \mathrm{M}\end{array}$ & (127) \\
\hline Quercetin-3-O-glucoside & $151 \mathrm{mg}$ & $\begin{array}{l}\mathrm{C}_{\max }=5.0 \mu \mathrm{M} \\
\mathrm{T}_{\max }=0.62 \pm 0.2 \mathrm{~h} \\
\mathrm{~T}_{1 / 2}=18.5 \pm 0.8 \mathrm{~h} \\
\mathrm{AUC}_{(0-72 \mathrm{~h})}=19.1 \mu \mathrm{M} \mathrm{h}\end{array}$ & $3.0 \%$ & (128) \\
\hline Quercetin-4'-O-glucoside & $154 \mathrm{mg}$ & $\begin{array}{l}C_{\text {max }}=4.5 \mu \mathrm{M} \\
T_{\max }=0.45 \pm 0.08 \mathrm{~h} \\
\mathrm{~T}_{1 / 2}=17.7 \pm 0.9 \mathrm{~h} \\
\mathrm{AUU}_{(0-72 \mathrm{~h})}=18.9 \mu \mathrm{M} \mathrm{h}\end{array}$ & $2.6 \%$ & \\
\hline Rutin & $94 \mathrm{mg}$ & $\begin{array}{l}C_{\max }=0.18 \mu \mathrm{M} \mathrm{h} \\
\mathrm{T}_{\max }=6.0 \pm 1.2 \mathrm{~h} \\
\mathrm{~T}_{1 / 2}=28.1 \pm 6.4 \mathrm{~h} \\
\mathrm{AUUC}_{(0-\infty)}=3.7 \mu \mathrm{M} \mathrm{h}\end{array}$ & NM & (129) \\
\hline
\end{tabular}




\begin{tabular}{|c|c|c|c|c|}
\hline $\begin{array}{l}\text { Food source/aglycone/ } \\
\text { glycoside }\end{array}$ & Quercetin dose & $\begin{array}{l}\text { Plasma } \\
\text { pharmacokinetics }\end{array}$ & $\begin{array}{l}\text { Urinary } \\
\text { excretion/ } \\
\text { concentration }\end{array}$ & Reference \\
\hline Quercetin-4'-O-glucoside & $94 \mathrm{mg}$ & $\begin{array}{l}\mathrm{C}_{\max }=3.5 \mu \mathrm{M} \mathrm{h} \\
\mathrm{T}_{\max }=\text { less than } 0.5 \mathrm{~h} \\
\mathrm{~T}_{1 / 2}=21.6 \pm 1.9 \mathrm{~h} \\
\mathrm{AUC}_{(0-\infty)}=18.8 \mu \mathrm{M} \mathrm{h}\end{array}$ & NM & \\
\hline Quercetin aglycone & $\begin{array}{l}1500 \mathrm{mg} \\
\text { (daily per } 1 \text { week) }\end{array}$ & $\begin{array}{l}\mathrm{C}_{\max }=5.110^{-5} \mu \mathrm{Mh} \\
\mathrm{T}_{\max }=3 \mathrm{~h} \\
\mathrm{~T}_{1 / 2}=3.47 \mathrm{~h} \\
\mathrm{AUUC}_{(0-\infty)}=0.21 \mu \mathrm{M} \mathrm{h}\end{array}$ & $1.18 \%$ & (130) \\
\hline $\begin{array}{l}\text { Quercetin aglycone with } \\
\text { fat-free muffin }(<0.5 \mathrm{~g} \text { fat) } \\
\text { Quercetin aglycone with low- } \\
\text { fat muffin ( } 4.0 \mathrm{~g} \text { fat) } \\
\text { Quercetin aglycone with fat- } \\
\text { free muffin ( } 15.4 \mathrm{~g} \text { fat) }\end{array}$ & 1095 mg & $\begin{array}{l}\mathrm{C}_{\text {max }}=1.1 \mu \mathrm{M} \\
\mathrm{T}_{\text {max }}=5.7 \mathrm{~h} \\
C_{\text {max }}=1.24 \mu \mathrm{M} \\
\mathrm{T}_{\text {max }}=5.4 \mathrm{~h} \\
C_{\text {max }}=1.6 \mu \mathrm{M} \\
\mathrm{T}_{\text {max }}=6.7 \mathrm{~h}\end{array}$ & NM & (6) \\
\hline
\end{tabular}

$C_{\max }$ : maximal plasma concentration; $T_{\max }$ : time to reach $C_{\max } ; T_{1 / 2}$ : elimination half-time; AUC: area under plasma concentration-time curve; NR: not reported; NM: not measured.

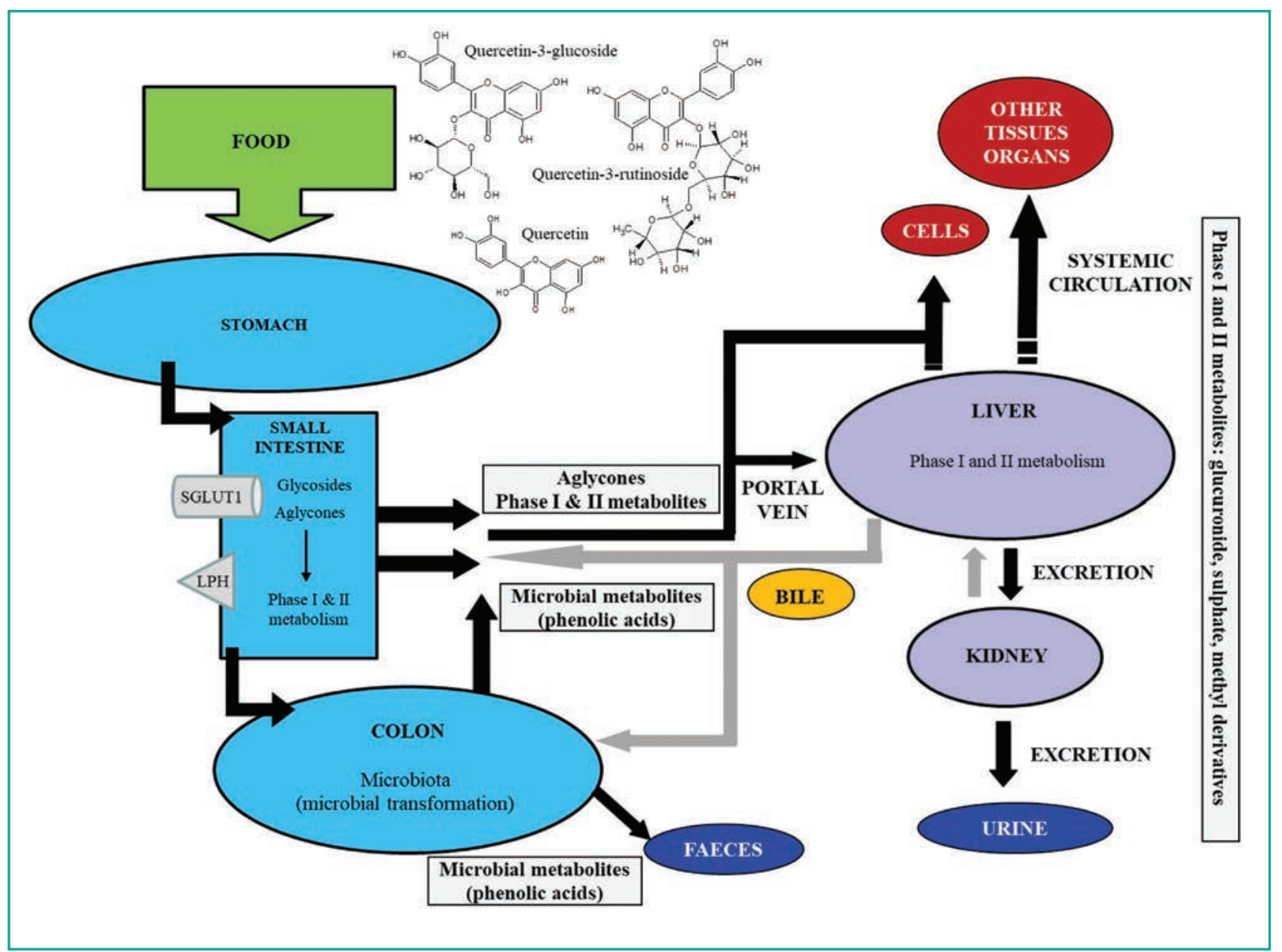

Figure 2. Major processes involved in oral bioavailability of quercetin in humans (see the text for details); SGLUT1: sodium-glucose cotransporter; LPH: lactase phlorizin hydrolase (adapted from Varoni et al., 2016 $(122))$. 
In conclusion, quercetin bioavailability is poor after a single oral intake and is characterized by high interindividual variability in its metabolism. According to pharmacokinetics data (table I), it seems that glucosides from onions possess a higher absorption rate compared to the glycosides from apples, tea, red wine or aglycones. Many factors may affect quercetin absorption including food matrix, dietary fat, vitamin $C$ status, sugar moieties, genetic polymorphisms, composition of gut microbiota, taking drugs, body mass index, lifestyle, and health status. However, there is no clear evidence demonstrating that gender and age affect quercetin bioavailability, although the existing studies involved a small number of volunteers. In any case, larger studies $(N \geq 20)$ are warranted to accurately evaluate bioavailability of quercetin, as well as more research is needed to develop (nano)formulations for improving its absorption and efficacy.

\section{GENERAL MECHANISMS}

\section{Induction of anti-proliferative effects}

Cancer progression is due to the uncontrolled growth of malignant cells, unable of either undergoing apoptosis or senescence. Therefore, the arrest of both proliferation and cell-cycle progression represents a relevant target of anticancer drugs. Quercetin elicits antitumor effects in different in vitro and in vivo models (9). In this regard, it has been demonstrated that quercetin suppressed hepatocellular carcinoma (HCC) cell proliferation in a concentration- and time-dependent manner as well as induced cell-cycle arrest at different phases, in relation to the cell line employed. Among the $13 \mathrm{HCC}$ cell lines tested, quercetin blocked cell cycle in G0/G1, S or G2/M phases in 4, 2 and 6 lines, respectively (10). In HepG2 cell lines, quercetin reduced cell proliferation along with lowering the expression of the checkpoint kinase-1 (CHEK1), leading to the downstream regulation of both cyclins $A$ and $E$ and hence the cell-cycle blockage (11). Moreover, an in vivo study revealed that the anticancer activity of quercetin against thioacetamide-induced HCC in rats was due to the inhibition of casein $\mathrm{ki}$ nase- $2 \alpha(C K 2 \alpha)$, which in turn induced the suppression of cyclin D1 and Ki-67, pivotal markers of proliferation (12). A study performed in cervical cancer cell line (HeLa) evidenced that quercetin anti-proliferative activity may be due to the downregulation of phosphatidylinositol 3-kinase (PI3K), mitogen-activated protein kinase (MAPK), and WNT pathways, leading to cell-cycle arrest in G2/M phase (13). Furthermore, quercetin blocked the cell cycle at the sub-G1 phase in gemcitabine-resistant pancreatic cancer cells (MIA Paca-2 GEMR), via a mechanism involving the reduction of the receptor for advanced glycation end products (RAGE), highly expressed by cancer cells, and the inhibition of the PI3K/Akt/mTOR axis (14). In addition, quercetin enhanced the effect of paclitaxel in prostate cancer cells (PC-3), where it significantly inhibited cell proliferation and arrested cell cycle at the G2/M phase (15). Finally, Soll and co-workers showed that quercetin hindered melanoma cells (B16) proliferation equal to etoposide, by increasing sub-G1 population, suggesting apoptotic cell death (16). The reported evidence summarized in table II suggests the anti-proliferative and cell-cycle blocking properties of quercetin in a wide plethora of cancers both in vitro and in vivo.

\section{Induction of cell death}

Quercetin exerts its anticancer activity by promoting multiple cancer cell death mechanisms (figure 3). Cell death is classified into two main categories: programmed and unscheduled, as necrosis. Apoptosis is the most known and characterized programmed cell death (PCD) mechanism. It is caspase-dependent and relies upon two main pathways: the intrinsic (or mitochondrial) and the extrinsic (or death receptor) pathway (17). A plethora of studies reported quercetin's ability to promote intrinsic, extrinsic or both apoptotic pathways in multiple cancer cell models including breast, colon, 
S. Adorisio, M. P. Argentieri, P. Avato, et al.

Table II. Effects of quercetin on cell-cycle progression.

\begin{tabular}{|l|l|l|l|l|}
\hline Effects on Cell Cycle & Concentration/dose & $\begin{array}{l}\text { Time of } \\
\text { exposure }\end{array}$ & $\begin{array}{l}\text { Experimental } \\
\text { model }\end{array}$ & Reference \\
\hline $\begin{array}{l}\text { Blockage of G0/G1, S or G2/M } \\
\text { phases }\end{array}$ & $25-100 \mu \mathrm{M}$ & $48 \mathrm{~h}$ & 13 HCCa cell lines & $(10)$ \\
\hline $\begin{array}{l}\text { Reduction of CHK1 and } \\
\text { cyclins A/E }\end{array}$ & $20-100 \mu \mathrm{M}$ & $48 \mathrm{~h}$ & HepG2 cells & $(11)$ \\
\hline $\begin{array}{l}\text { Block in G2/M phase via } \\
\text { downregulation of PI3K, } \\
\text { MAPK and WNT pathways }\end{array}$ & $25-50 \mu \mathrm{M}$ & $24-48 \mathrm{~h}$ & HeLa cells & $(13)$ \\
\hline $\begin{array}{l}\text { Sub-G1 population increase, } \\
\text { via RAGE involvement and } \\
\text { modulation of PI3K/AKT/ } \\
\text { mTOR axis }\end{array}$ & $25-200 \mu \mathrm{M}$ & $48 \mathrm{~h}$ & $\begin{array}{l}\text { MIA Paca-2 GEMR } \\
\text { cells }\end{array}$ & $(14)$ \\
\hline $\begin{array}{l}\text { Reduction of BTG2, p21 and } \\
\text { p27 expression }\end{array}$ & $\begin{array}{l}11.39 \mu \mathrm{M}(+2.85 \mu \mathrm{M} \text { of } \\
\text { curcumin) }\end{array}$ & $48 \mathrm{~h}$ & K562 cells & $(131)$ \\
\hline $\begin{array}{l}\text { Fall of CK2 } \alpha, \text { cyclin D1 and } \\
\text { Ki-67 expression }\end{array}$ & $100 \mathrm{mg} / \mathrm{kg}$ & $\begin{array}{l}5 \text { days/week } \\
(8 \text { weeks in } \\
\text { total) }\end{array}$ & $\begin{array}{l}\text { Thioacetamide- } \\
\text { induced HCCa in } \\
\text { rats }\end{array}$ & $(12)$ \\
\hline Increase of cells in sub-G1 & $50 \mathrm{mg} / \mathrm{mL}$ & $24-48 \mathrm{~h}$ & B16 cells & $(16)$ \\
\hline $\begin{array}{l}\text { Arrest of cell cycle at the } \\
\text { G2/M phase }\end{array}$ & $20 \mu \mathrm{M}$ & $24 \mathrm{~h}$ & PC-3 cells & $(15)$ \\
\hline
\end{tabular}

${ }^{a}$ Hepatocellular carcinoma.

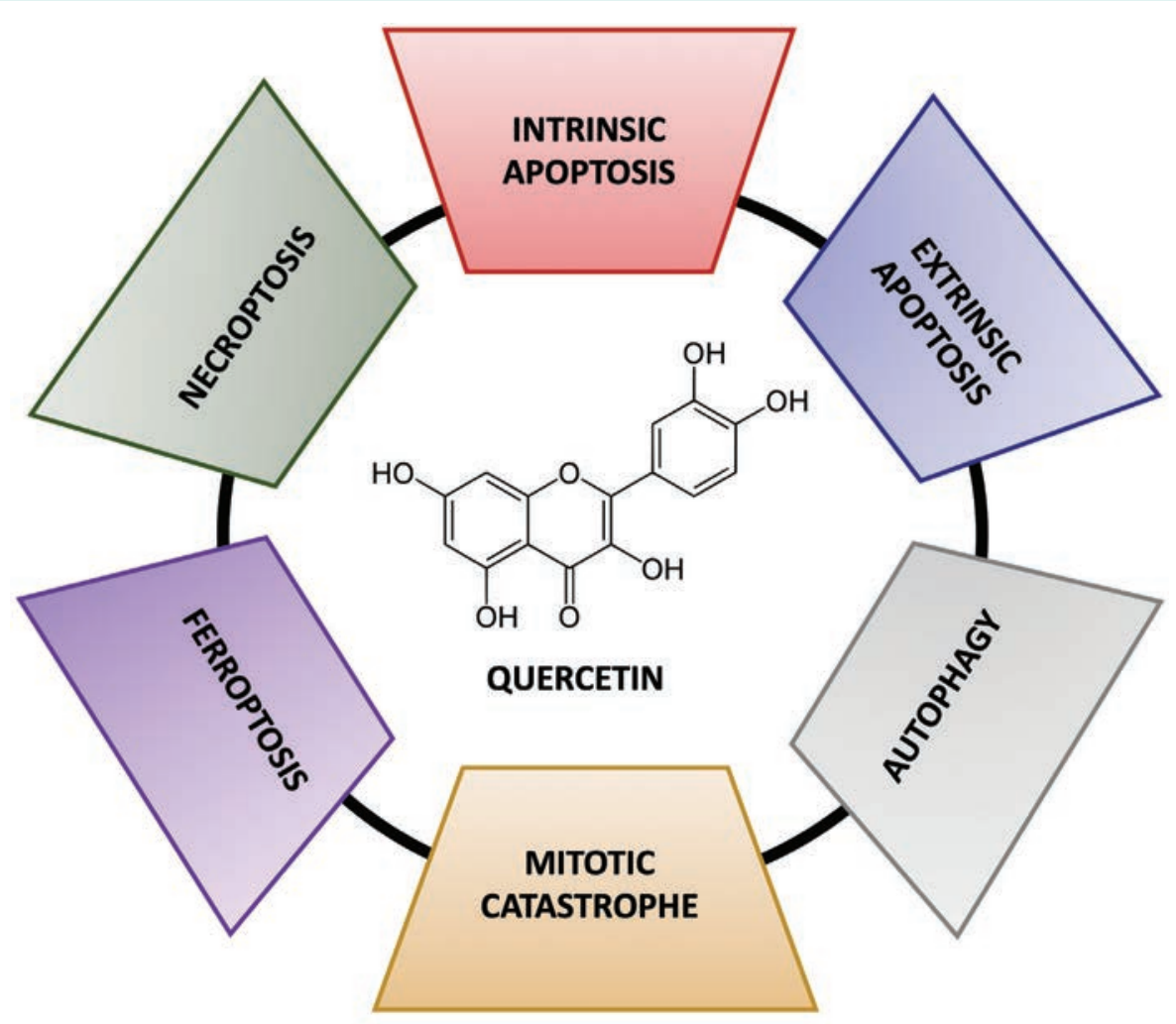

Figure 3. Schematic representation of quercetin-induced cell death mechanisms. 
liver, lung and gastric cancer, melanoma, glioma, and leukemia, both in vitro $(20-350 \mu \mathrm{M})$ and in vivo $(10-500 \mathrm{mg} / \mathrm{kg})(9,18,19)$.

Apart from apoptosis, also autophagy represents a PCD mechanism. Although in most cases autophagy acts as a protective cellular process, thus eventually promoting tumor progression, in other circumstances autophagy can lead to cell death (17). As recently reviewed, quercetin promoted in vitro (12.5-160 $\mu \mathrm{M})$ and in vivo $(50-120 \mathrm{mg} / \mathrm{kg})$ autophagic cell death and/or cytoprotective autophagy in leukemia, glioma, gastric, breast, ovarian (20), and lung cancer (21).

Accumulating evidence points out that multiple non-apoptotic forms of PCD also called non-canonical, can be triggered through independent apoptosis when the apoptotic process is altered or inhibited. Ferroptosis is an iron-dependent non-canonical PCD mechanism, driven by the accumulation of lipid peroxides. In hepatocellular carcinoma HepG2 cells, quercetin $(50 \mu \mathrm{M})$ promoted both apoptosis and ferroptosis (22). Indeed, lysosome-dependent cell death induced by quercetin was associated with the promotion of ferritin degradation (22), a process known as ferritinophagy, which enhances the cellular free iron content, thus increasing lipid peroxidation and promoting ferroptotic cell death (23). Necroptosis, instead, relies on the activation of RIPK1 (receptor interacting serine/ threonine kinase 1) that leads to the formation of the so-called necrosome complex. Notably, in MCF-7 breast cancer cells, quercetin (50 $\mu \mathrm{M}$ ) suppressed cell proliferation by promoting both apoptosis and necroptosis. Indeed, the inhibition of RIP1K by necrostatin-1 as well as the inhibition of apoptosis by Z-VAD-fmk (a pan-caspase inhibitor) restored MCF-7 cell viability, pointing out quercetin's ability to trigger these two cell death pathways (24).

Lastly, mitotic catastrophe (MC) is a type of PCD occurring during mitosis because of severe DNA damage, impaired mitotic machinery, and/or failure of mitotic control points (25). A549 non-small cell lung cancer cells treated with quercetin $(10-60 \mu \mathrm{M})$ displayed monopolar and multipolar spindles, misaligned and mis-segregated chromosomes (26), all features related to MC (25). In addition, polyploi$d y$, cell enlargement, and multinucleation, observed in A549-treated cells, further confirmed the induction of mitotic catastrophe by quercetin (26).

\section{Inhibition of cancer cells' migration and invasion}

The progression of cancer development may lead to the acquisition by tumor cells of the ability to invade nearby tissues and form metastases in other organs, representing so far one of the greatest challenges in oncology (27). Quercetin was reported to block both migration and invasion of non-small cell lung cancer cells, in vitro and in a xenograft mice model, through the inhibition of the Src-mediated Fn14/NF-kB pathway, known to promote cell survival and metastatic capabilities of cancer cells (28). Moreover, Guo and co-workers showed that quercetin hindered metastasis of pancreatic ductal adenocarcinoma cells, both in vitro and in vivo, via the inhibition of sonic hedgehog and tumor grow factor (TGF)- $\beta$ / Smad signaling pathways, that in turn brought to a suppression of the epithelial-mesenchymal transition (EMT) of these cells. This process involves the acquisition of the mesenchymal stem cells phenotype by epithelial ones and, in pathological conditions, it leads to resistance and migration of cancer cells (29). The effect on EMT was observed also both in skin squamous carcinoma, where quercetin inhibited migration and invasion through the reduction of Src/STAT3/S100A7 signaling pathway (30) and in different oral squamous carcinoma cells, where its treatment negatively affected both matrix metalloproteinase (MMP) and TGF- $\beta 1$ expression (31). In this last type of cancer, quercetin also hampered migration and invasion by regulating micro-RNA-16 and homeobox $A 10$, relevant in the correct regulation of cell proliferation (32). The anti-metastatic properties of quercetin have been also evaluated 
in osteosarcoma cell lines, in which it reduced the expression of MMPs and increased that of their tissue inhibitors (TIMPs), along with affecting the parathyroid hormone receptor-1, a typical biomarker of metastatic osteosarcoma cells (33). MMPs and cadherins, markers of mesenchymal and epithelial cells, respectively, have been shown to be modulated by quercetin in estrogen-receptor (ER) positive breast carcinoma (BRC) cells, along with potentiating antitumor activity of tamoxifen (34), as well in ovarian metastatic cancer cells, where it inhibited also PI3K/Akt, Ras/Raf pathways, EGFR, and claudins expression, therefore polarizing cells towards the epithelial state (35). Triple-negative BRC cells have been employed to study the anti-migration and anti-invasion properties of quercetin, demonstrating to be an inhibitor of the PI3K/Akt pathway together with MAPK one (36). Another relevant pathway in metastasis is JAK/STAT one, which was demonstrated to be affected by quercetin in hepatocarcinoma cells both in vitro and in vivo (37). Additionally, Lu and collaborators showed that quercetin treatment decreased the expression of Twist2 and EpCAM and increased that of E-cadherin, other pivotal factors involved in EMT, in prostate cancer cells resistant to docetaxel (38). Overall, these reports, summarized in table III, support the remarkable value of quercetin as an anti-metastatic agent, given its capability to hamper EMT transition by simultaneously targeting both membrane and intracellular signaling pathways leading to the up-regulation of multiple factors involved in invasion and migration of cancer cells.

Table III. Main migration- and invasion-related pathways affected by quercetin in different cell lines.

\begin{tabular}{|l|l|l|l|l|}
\hline $\begin{array}{l}\text { Migration-/invasion-related } \\
\text { pathways }\end{array}$ & Concentration & $\begin{array}{l}\text { Time of } \\
\text { exposure }\end{array}$ & Type of cancer & Reference \\
\hline $\begin{array}{l}\text { Decrease of MMPs, cadherins, } \\
\text { EGFR and claudins expression; } \\
\text { blockage of PI3K/Akt and Ras/Raf } \\
\text { pathways }\end{array}$ & $50-75 \mu \mathrm{M}$ & $24 \mathrm{~h}$ & $\begin{array}{l}\text { Ovarian metastatic } \\
\text { cancer }\end{array}$ & $(35)$ \\
\hline $\begin{array}{l}\text { Inhibition of the Src-mediated } \\
\text { Fn14/NF-kB }\end{array}$ & $100 \mu \mathrm{M}$ & $48 \mathrm{~h}$ & $\begin{array}{l}\text { Non-small cell lung } \\
\text { cancer }\end{array}$ & $(28)$ \\
\hline $\begin{array}{l}\text { Inhibition of Src/STAT3/S100A7; } \\
\text { blockage of EMT }\end{array}$ & $20-40 \mu \mathrm{M}$ & $24 \mathrm{~h}$ & $\begin{array}{l}\text { Skin squamous } \\
\text { carcinoma }\end{array}$ & $(30)$ \\
\hline $\begin{array}{l}\text { Inhibition of hedgehog and TGF- } \beta / \\
\text { Smad; blockage of EMT }\end{array}$ & $10-100 \mu \mathrm{M}$ & $24-48 \mathrm{~h}$ & $\begin{array}{l}\text { Pancreatic ductal } \\
\text { adenocarcinoma }\end{array}$ & $(29)$ \\
\hline $\begin{array}{l}\text { Decrease of MMP and TGF- } \beta 1 \\
\text { expression }\end{array}$ & $40 \mu \mathrm{M}$ & $24 \mathrm{~h}$ & $\begin{array}{l}\text { Oral squamous } \\
\text { carcinoma }\end{array}$ & $(31)$ \\
\hline $\begin{array}{l}\text { Suppression of MMPs, TIMPs and } \\
\text { parathyroid hormone receptor-1 }\end{array}$ & $20-100 \mu \mathrm{M}$ & $48 \mathrm{~h}$ & Osteosarcoma & $(33)$ \\
\hline $\begin{array}{l}\text { Decrease of Twist2 and EpCAM } \\
\text { and increase of E-cadherin } \\
\text { expressions }\end{array}$ & $10 \mu \mathrm{M}$ & $48 \mathrm{~h}$ & $\begin{array}{l}\text { Docetaxel-resistant } \\
\text { prostate cancer }\end{array}$ & $(38)$ \\
\hline $\begin{array}{l}\text { Inhibition of PI3K/AKT and MAPK } \\
\text { pathways }\end{array}$ & $25-50 \mu \mathrm{M}$ & $24-48 \mathrm{~h}$ & $\begin{array}{l}\text { Triple-negative } \\
\text { breast cancer }\end{array}$ & $(36)$ \\
\hline Blockage of JAK/STAT pathway & $80-120 \mu \mathrm{M}$ & $12-36 \mathrm{~h}$ & Hepatocarcinoma & $(37)$ \\
\hline $\begin{array}{l}\text { Inhibition of MMPs and cadherins } \\
\text { expression }\end{array}$ & $5-100 \mu \mathrm{M}$ & $48 \mathrm{~h}$ & $\begin{array}{l}\text { Estrogen-receptor } \\
\text { positive breast } \\
\text { carcinoma }\end{array}$ & $(34)$ \\
\hline $\begin{array}{l}\text { Regulation of micro-RNA-16 and } \\
\text { homeobox A10 }\end{array}$ & $25-100 \mu \mathrm{M}$ & $24-48 \mathrm{~h}$ & $\begin{array}{l}\text { Oral squamous } \\
\text { carcinoma }\end{array}$ & $(32)$ \\
\hline
\end{tabular}




\section{Epigenetic mechanisms}

Recent research has shown that post-transcriptional histone modifications, changes in DNA methylation status, and regulation of non-coding RNAs can alter gene expression and modify the development of several types of cancer (39).

Studies using human xenografts and acute myeloid leukemia cell lines (HL60 and U937) have shown that treatment with quercetin $(50 \mu \mathrm{M})$ downregulates histone deacetylase I (HDACl) protein levels, leading to DNA demethylation and accumulation of acetylated histones 3 and 4 in the promoter regions of genes involved in apoptosis pathways, leading to their transcriptional activation (40). Recently, a novel chitosan-based quercetin nanohydrogel (ChiN$\mathrm{H} / \mathrm{Q}$ ) has been reported to reduce the inhibition of DNA methyltransferases (DNMT1/3A/3) and increase DNA methylation in HepG2 cancer cells with a half maximal inhibitory concentration $\left(\mathrm{IC}_{50}\right)$ of $331 \mu \mathrm{M}$ (41). Moreover, overexpression of the enzyme HDAC8 is another important epigenetic alteration that has been reported in colon cancer. Its inhibition in HCT116 cells by quercetin $\left(\mathrm{IC}_{50}: 181.7 \mu \mathrm{M}\right)$ leads to increased acetylated H3K9 (histone H3, lysine 9) and apoptosis through the activation of caspase-3/-7 (42). Regarding the control of post-transcriptional mechanisms, experimental studies suggested that quercetin $50 \mu \mathrm{M}$ modulates the expression of DBH-AS1, which is an important epigenetic reader in cancer therapy. Moreover, quercetin (0.87-7.79 $\mu \mathrm{M})$ inhibition of carbonic anhydrase isoforms (CA II, CA IX, and CA XII) was observed in previous cancer studies (43). Recently, intravenous administration of quercetin-modified metal-organic frameworks (Zr-MOF-QU) $(50 \mathrm{mg} / \mathrm{kg})$, a novel type of $\mathrm{Zr}$ MOF nanoparticles, showed excellent efficiency for CA IX inhibition in tumor-bearing mice (44). Several in vitro studies showed that quercetin was able to upregulate the miR-let $7 \mathrm{mi}$ cro-RNA family in pancreatic ductal adenocarcinoma cells, thus interfering with K-Ras's pathways. Furthermore, miR-16, miR-217, and miR-145 were found to be modulated by quercetin $(0.5-100 \mu \mathrm{M})$ in lung adenocarcinoma, osteosarcoma, and ovarian cancer cells, respectively. In particular, miR-145 was shown to inhibit and control target genes involved in apoptosis, thus demonstrating the ability of quercetin to influence micro-RNA expression patterns related to cancer (45).

An interesting study reported that quercetin $(20 \mu \mathrm{M})$ increases the efficacy of bromodomain and extraterminal domain inhibitors by suppressing the heterogeneous nuclear ribonucleoprotein A1, a nuclear protein, controlling mRNA translation and transport, as well as by decreasing survivin, an antiapoptotic protein (46), in several tumor cell lines. An in-depth study was carried out to understand the mechanism of action of quercetin by quantifying the biochemical activity of DNA methyltransferases, HDACs, histone methyltransferases, and methylation of oncosuppressor gene selections and global genomic DNA methylation on treated HeLa cells. Enzymatic assays showed that quercetin 25 and $50 \mu \mathrm{M}$ modulates these activities in a dose-dependent manner, while molecular docking studies suggested that quercetin could be a competitive inhibitor by interacting with residues within the catalytic cavity of several DNA methyltransferases and HDACs (47).

Future research has the potential to expand the use of dietary-based polyphenols, such as quercetin, in treating cancer, especially in combination with conventional drugs. Their use could be an alternative and effective method in cancer therapy leading to restoration of several aberrant epigenetic alterations.

\section{Angiogenesis}

The ability to induce the formation of new blood vessels is one of the peculiar activities of cancer cells, which allows them to better access nutrients and oxygen and constitutes an excellent way of tumor dissemination (48). Quercetin modulates different cell signaling pathways involved in angiogenesis (figure 4). The modulation of vascular endothelial growth factor (VEGF) pathway seems to be 


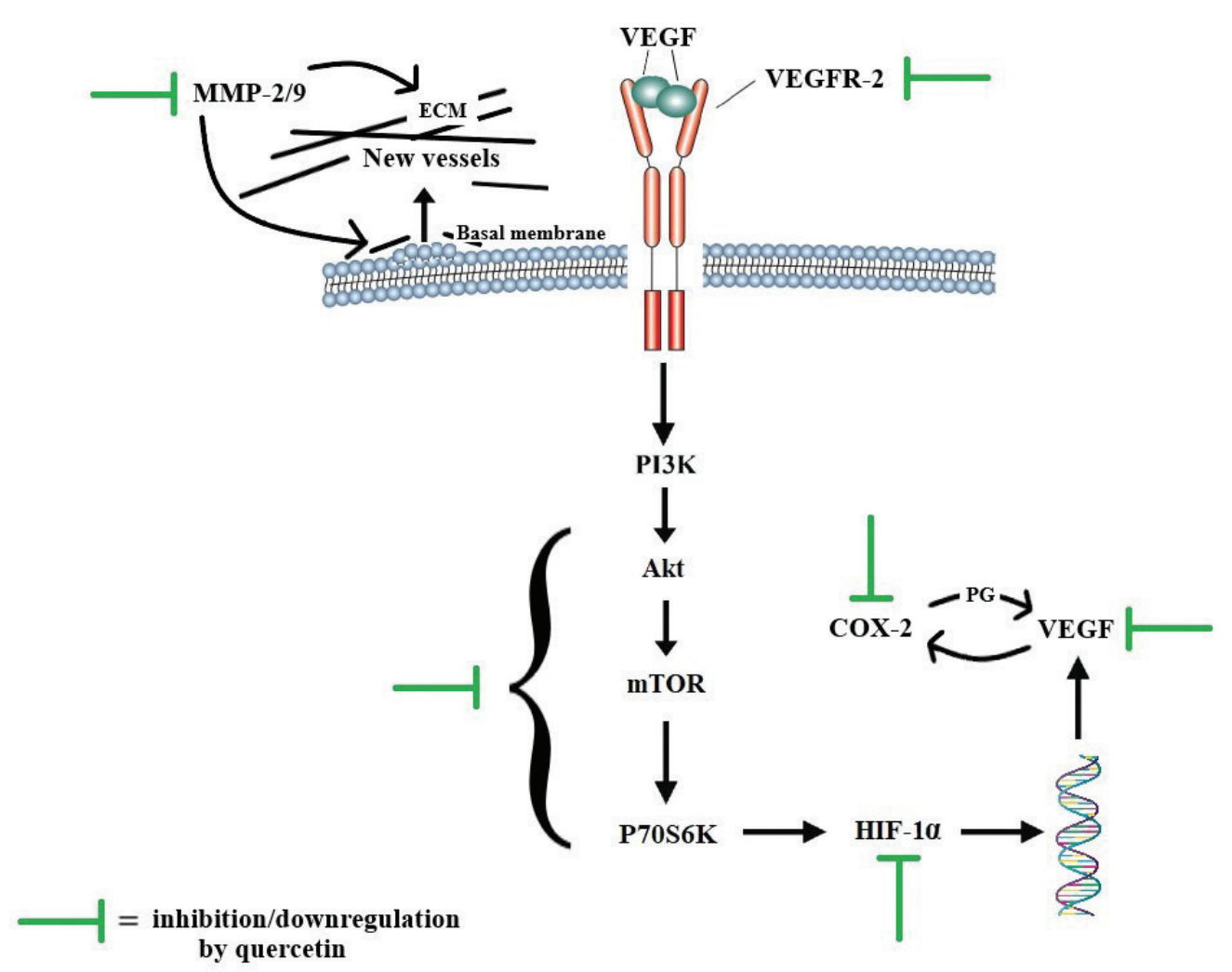

Figure 4. Major angiogenesis signaling pathways modulated by quercetin.

especially involved in this effect, considering its well-known key role in survival of endothelial cells and related tumor angiogenesis (49). In HUVEC cells, quercetin (10-40 $\mu \mathrm{M})$ blocked the VEGF-mediated phosphorylation of VEGF receptor 2 and its downstream protein kinases Akt, mTOR, and ribosomal protein $\mathrm{S} 6$ kinase (50). Similar results were recorded in PC-3 prostate cancer cells, where quercetin (10-40 $\mu \mathrm{M})$ inhibited the secretion of VEGF (50). Moreover, intraperitoneal administration of quercetin $(20 \mathrm{mg} / \mathrm{kg} /$ day) inhibited the activation of Akt, mTOR and P70S6K proteins and led to decreased tumor's weight and volume in a murine prostate xenograft model (50).

Balakrishnan et al. (51) studied the antiangiogenetic potential of a gold nanoparticle-based delivery system. The formulation (50-100 $\mu \mathrm{M})$ was able to inhibit MMP-2 and MMP-9 activity as well as to reduce the expression of p-EGFR/VEGFR-2 and p-PI3K/Akt/p-Akt/p-
GSK-3 $\beta$ downstream signalling molecules on human breast cancer cell lines (MCF-7 and MDAMB-231) and the expression of VEGFR-2 in HUVECs. Similar results were recorded on chick embryos, where the formulation at 50 $\mu \mathrm{M}$ inhibited neovascularization.

Analogously, Lupo et al. suggested that quercetin and its permethylated form at $25 \mu \mathrm{M}$ inhibited cell viability and migration, downregulated VEGFR-2 and reduced Akt, ERK and JNK levels on human primary endothelial cells isolated from retinal microcapillaries (HREC). Similar results were obtained on an ex vivo model of rabbit aortic ring, where quercetin and its permethylated form disrupted microvessels formation (52).

A study performed on an abdominal aortic aneurysm (AAA) mouse model also demonstrated that quercetin $(60 \mathrm{mg} / \mathrm{kg})$ decreased neovascularization and the expression of proangiogenic mediators, including VEGF-A, intercellular adhesion molecule 1 (ICAM-1), vas- 
cular cell adhesion molecule 1 (VCAM-1) and vascular endothelial cadherin, and inhibited the expression of cyclooxygenase-2 (COX-2) and hypoxia-inducible factor $1 \alpha$ (HIF-1 $\alpha$ ), associated with the upregulation of VEGF-A. The same study showed that quercetin-3-O-glucuronide, a quercetin major circulating metabolite, downregulated COX-2, HIF-1 $\alpha$ and VEGF-A expression and matrix metalloproteinases MMPs activities in vascular smooth muscle cells isolated from AAA mice after $72 \mathrm{~h}$ treatment at a concentration of $50 \mu \mathrm{M}$ (53). A similar decreased expression of proangiogenic mediators and metastasis-associated factors, such as VEGF-A, VEGFR-2, COX-2, E-cadherin, Twist1 gene and integrin ITG $\beta 6$, was observed in a human gastric cancer xenograft mouse model after treatment with quercetin $(20 \mathrm{mg} / \mathrm{kg})$ or even more with its combination with the antitumoral drug irinotecan (54). It was also found that low concentration of quercetin $(10 \mu \mathrm{g} / \mathrm{mL})$ inhibited tube formation in HUVECs treated with conditioned medium obtained from U251 glioblastoma cells possibly by downregulating VEGF-A and MMP-2 and MMP-9 protein levels (55).

Finally, the intravenous administration of polymer micelle-nanoencapsulated quercetin $(60$ $\mathrm{mg} / \mathrm{kg}$ ) significantly suppressed the growth of xenograft $A 2780 S$ ovarian tumors in athymic nude mice through a significantly inhibition of microvessel density. Moreover, treating A2780S cells with quercetin $(0-30 \mu \mathrm{g} / \mathrm{mL}, 48 \mathrm{~h})$ in vitro produced higher levels of phosphorylated p44/42 MAPK and phosphorylated Akt, which are critical intracellular mediators of angiogenesis (56).

\section{EFFECT OF QUERCETIN ON THE MOST COMMON CANCERS}

\section{Breast cancer}

The anticancer activity of quercetin on breast cancer (BRC) is mediated via regulation of various signaling pathways, but the exact mechanism of its action remains elusive. In a
HER2-overexpressing (BT-474) BRC cell line, quercetin $(20-60 \mu \mathrm{M})$ activated the extrinsic apoptotic pathway. In MDA-MB-231 cells, quercetin modulated the Akt/AMPK/mTOR pathway (57) and, besides the effects on signaling proteins, at $20 \mu \mathrm{M}$ it increased the activity of several cell-cycle regulatory proteins such as p53, p21, and GADD45 (58). In the same cell line, quercetin $(20-80 \mu \mathrm{M})$ inhibited aerobic glycolysis via impairing PFKP-LDHA axis (59). Those results were confirmed in a xenograft BRC model, where quercetin $(50 \mathrm{mg} / \mathrm{kg}$ twice daily intraperitoneally for a month) suppressed glycolysis and tumor metastasis (60). Quercetin $100 \mu \mathrm{M}$ was also able to inhibit migration and invasion of BRC stem cells via ALDH1A1, CXCR4, and EpCAM downregulation (61). The exposure of BRC cell lines to quercetin $(50$ and $100 \mu \mathrm{M})$ reduced the expression of SLUG, SNAIL, and Twist transcription factors, while up-regulated E-cadherin, thus suggesting that quercetin can act as an EMT inhibitor (58). In a study by D'Arrigo et al. performed on MCF-7 (wild-type p53) and T47D (mutant p53) cells (62), quercetin, like other flavonoids, showed a relevant degree of complementarity with estrogen and androgen receptors (62) and inhibited the survival of ER+ tumor-initiating cells (63). Moreover, an in silico and in vitro screening indicated that quercetin had also a high binding affinity for the cyclin-dependent kinase 6 (CDK6) and inhibited $50 \%$ of its ATPase activity at $5.89 \mu \mathrm{M}$ (64).

A novel nanoformulation of quercetin composed of hyaluronic acid, copper ion, chelated dextran-aldehyde was tested on MDA-MB-231 cells and BRCA-mutant TNBC HCC1395 cells. The formulation was highly cytotoxic for HCC1395 cells, where it induced DNA damage and apoptosis. In HCC1395-tumor-bearing nude mice, treatment with the nanoformulation induced a decrease in tumor volume higher than that observed for quercetin (65).

As a potent heat shock protein (HSP) 70 inhibitor, quercetin $(50 \mu \mathrm{M})$ was used as sensitizer in a new modulated electro-hyperthermia treatment. On 4T1 murine BRC cells, querce- 
tin synergistically decreased cell viability with respect to the two single pharmacological strategies (66). As a P-gp inhibitor, nanoformulated quercetin plus paclitaxel was tested both in vitro and in vivo. In MCF-7 cells, quercetin $33 \mu \mathrm{M}$ decreased the efflux of paclitaxel and synergistically enhanced its cytotoxicity; in xenograft MCF-7 BRC, intravenous administration of quercetin $(5.1 \mathrm{mg} / \mathrm{kg})$ decreased tumor weight without toxicity to normal tissues (67). Moreover, the inhibitory effects of quercetin on CYP450 enzymes were exploited to improve mycophenolic acid's anticancer activity on 7,12-dimethylbenz(a)anthracene-treated rats (68). In conclusion, the pleiotropic activity of quercetin against BRC and in particular its ability to sensitize cancer cells and counteract drug resistance makes it a promising candidate for well-designed oncological clinical trials.

\section{Ovarian and prostate cancers}

Several studies have been conducted to elucidate the molecular mechanisms of quercetin's activity on ovarian cancer (OC). Quercetin inhibited cells' growth and promoted apoptosis in a concentration-dependent manner in different $\mathrm{OC}$ cell lines. As an example, its proapoptotic activity was observed on A2780S cells, where quercetin $(0.4-100 \mu \mathrm{M})$ activated caspase-3 and -9 , reduced the expression of MCL-1 and Bcl-2, and increased the expression of Bax. Moreover, on the same cell line, it inhibited cell proliferation through the reduction of phosphorylated p44/42 MAPK and phosphorylated Akt (56). Similar results were recorded in SKOV3 CDDP3 cisplatin-resistant cells, where quercetin $(10-50 \mu \mathrm{M})$ interfered with the G2/M phase, even if it did not affect cyclin B1 levels (69). Besides, quercetin $20 \mu \mathrm{M}$ induced endoplasmic reticulum stress in cisplatin-sensitive OV2008 cells and their resistant variant resulting in mitochondria-mediated apoptosis via a p-STAT3/Bcl-2 and caspase-dependent pathways (70), as demonstrated by Bcl-2 and $\mathrm{Bcl}-\mathrm{xL}$ reduction and caspase-3, -9, Bid, Bax, Bad, and cytochrome c increase. Similarly, quercetin at 50 and $75 \mu \mathrm{M}$ decreased viability and induced apoptosis on human metastatic PA-1 cells, as indicated by $\mathrm{Bcl}-2$ and $\mathrm{Bcl}-\mathrm{xL}$ decrease and caspase-3, caspase-9, Bid, Bad, Bax, and cytochrome $c$ increase (71). A recent study tested the antitumor effects of quercetin encapsulated into monomethoxy poly(ethylene glycol, PEG)-poly( $\varepsilon$-caprolactone) micelles (56). The nanoformulation $(60 \mathrm{mg} / \mathrm{kg}$ ) significantly inhibited tumor volume, induced apoptosis and strongly inhibited angiogenesis of xenograft A2780S ovarian tumors. Of note, the nanoformulation was well tolerated, as indicated by no changes in animals' body weight (56).

Furthermore, the effect of a quercetin-PEGylated liposomal formulation was investigated in sensitive and cisplatin-resistant A2780 ovarian cancer cells. The formulation $(50 \mu \mathrm{M})$ caused apoptosis and G0/G1 and G2/M arrest, as well as inhibited cell proliferation of both clones. In vivo studies performed on xenograft sensitive or cisplatin-resistant A2780 ovarian tumors, found that the formulation $(50 \mathrm{mg} / \mathrm{kg}$ ) blocked tumor growth in both mice models (72).

On prostate cancer (PC) LNCaP cells, quercetin $100 \mu \mathrm{M}$ decreased $\mathrm{Bcl}-\mathrm{xL} / \mathrm{BCl}-\mathrm{xS}$ ratio and amplified the efflux of Bax to the mitochondrial matrix leading to apoptosis (73). In addition, quercetin (5-100 $\mu \mathrm{M}$ ) downregulated HSP90 expression and led to growth inhibition and apoptosis of PC-3 cells (74). In the same cell line, quercetin $(25-125 \mu \mathrm{M})$ inhibited cell viability by reducing the mRNA expression of different mitogenic factors including insulin-like growth factors (IGF)-I and II and increased that of IGFBP-3Rbeta, which led to a reduced secretion of IGF-I and II (75).

A recent study reported that quercetin (50$500 \mu \mathrm{M})$ reduced the expression of metastasis-associated lung adenocarcinoma transcript 1 (MALAT1), which is overexpressed in PC, induced apoptosis, and blocked EMT and invasion and migration of PC-3 cells (38). Those results were confirmed on a mouse PC-3 xenograft tumor, where intraperitoneal quercetin $(75 \mathrm{mg} / \mathrm{kg})$ targeted MALAT1 and blocked 
tumor growth (38) and angiogenesis through an increase in thrombospondin-1 protein and mRNA expression (76).

Several in vivo studies recorded the quercetin's ability of enhancing the therapeutic effect of different drugs. The combination of quercetin $(50 \mathrm{mg} / \mathrm{kg}$ ) and paclitaxel $(5 \mathrm{mg} /$ $\mathrm{kg}$ ) synergized the inhibition of tumor growth induced by paclitaxel alone in a mouse PC-3 xenograft tumor (15). Moreover, quercetin (75 $\mathrm{mg} / \mathrm{kg}$ ) synergized with 2-methoxyestradiol in inhibiting tumor growth, increasing $\mathrm{Bax} / \mathrm{Bcl}-2$ ratio and caspase- 3 activation, and reducing microvessel density in both androgen-dependent LNCaP and androgen-independent PC-3 xenograft tumors (77) and was able to reverse docetaxel resistance (78).

The cancer preventive effect of quercetin was also highlighted in a clinical trial where 433 men with confirmed primary PC and 538 controls were evaluated in a case-control study: $24 \mathrm{mg}$ intake of quercetin/day reduced PC risk by $27 \%(79)$.

\section{Lung cancer}

Lung cancer (LC) includes both small cell lung cancer and non-small cell LC (NSCLC), despite the latter alone is responsible for $85 \%$ of tumors in this organ (80). Several in vitro studies reported the antiproliferative and pro-apoptotic activity of quercetin on LC cells, mediated by both intrinsic and extrinsic pathways (18). For instance, in NSCLC cells quercetin prompted mitochondrial depolarization triggering an imbalance in the $\mathrm{Bax} / \mathrm{Bcl} 2$ ratio and downregulating IL-6/STAT3 signaling pathway. Besides, quercetin triggered TRAIL-induced apoptosis by TNF-family death receptors binding $(9,18)$ and by the regulation of epigenetic pathways (81). In particular, in the p53-mutant $\mathrm{H} 1299$ LC cells, quercetin $5 \mu \mathrm{M}$ raised p300 expression, which is responsible for the acetylation of the lysine residues of histones. Thanks to this mechanism, quercetin enhanced the expression of the death receptor DR5 and the anticancer effects of HDAC inhibitors (trichostatin and vorinostat) (81).
Due to the Janus face of autophagy, the effect of quercetin-activated autophagy on apoptosis is complicated, since it could be partner or opponent (82). A very recent publication unraveled that quercetin (12.5-100 $\mu \mathrm{M})$ induced pro-apoptotic autophagy in two NSCLC LC, A549 and H1299, involving the histone/protein deacetylase sirtulin 1 (SIRT1) and its downstream effector AMPK (AMP-activated protein kinase), potent stimulators of cellular autophagy (21).

Cytoskeleton components, such as microtubules, microfilaments and vimentin, are key targets for anticancer treatment, due to their importance in the regulation of mitosis, cell division, cell migration, and cell death (83). Quercetin $(10-60 \mu \mathrm{M})$ impacted on these essential cytoskeletal elements, disassembling vimentin, microfilaments, and microtubules in A549 cells and contributing to the failure of cytokinesis, which leads to apoptosis and mitotic catastrophe (26). Besides, the inhibition by quercetin of vimentin and $\mathrm{N}$-cadherin (26), both markers of EMT, contrasted A549 migration, hence their metastatic potential. A recent study highlighted that the inhibition by quercetin of NSCLC cells (HCC827) proliferation and migration was also mediated by the Src family kinases (28), high levels of which activate Fn14/NF-kB signaling and promote the metastatic potential of NSCLC cells (84). Other in vitro $(100 \mu \mathrm{M})$ and in vivo (HCC827 xenografted BALB/C mice intraperitoneally treated with $100 \mathrm{mg} / \mathrm{kg} /$ day quercetin for 3 weeks) studies confirmed that the anti-NSCLC effects of quercetin clearly depended on the inhibition of Src.

Receptor tyrosine kinases (RTKs) represent one of the most frequently deregulated family of proteins in LC, playing a key role in the control of tumor cell proliferation (85). Through a computational studies, Baby and colleagues (86) demonstrated that quercetin mimics the interactions of ATP in the active site of RTKs (EGFR, FGFR1, IGF1R and c-Met) leading to inhibition of RTKs overexpression.

A recent in silico screening and in vitro experiments evidenced that the pro-apoptotic ef- 
fects of quercetin $(\sim 50 \mu \mathrm{M})$ involve the inhibition of CDK6 (64), the nuclear expression of which is negatively associated with the overall survival of lung cancer patients (87).

Different quercetin-loaded nanoparticles synergistically enhanced the anticancer efficacy of paclitaxel $(88,89)$ and gefitinib $(90)$ in vitro and in vivo. As an example, quercetin and gefitinib encapsulated into PLGA-PEG nanoparticles synergistically reduced the $I_{50}$ values of the single drugs on PC-9 cells $\left(\mathrm{IC}_{50}\right.$ quercetin-nanoparticles: $2.12 \mu \mathrm{g} / \mathrm{mL} ; \quad I_{50}$ gefitinib-nanoparticles: $2.57 \mu \mathrm{g} / \mathrm{mL} ; I_{50}$ quercetin/ gefitinib-nanoparticles: $0.67 \mu \mathrm{g} / \mathrm{mL}$ ) (90).

\section{Colorectal cancer}

Quercetin has been shown to reduce proliferation and to induce apoptosis and cell-cycle arrest in a number of colorectal cancer (CRC) cells, such as HCT116, HT-29, SW 480, SW 620, Caco-2, LoVo, Colo320 DM cells (91). Specifically, van Erk et al. (2005) reported that $5 \mu \mathrm{M}$ quercetin downregulates key cell-cycle genes (e.g., CDK6, CDK4 and cyclin D1) in Caco-2 cells (92). Moreover, at 20, 50, 100 and $200 \mu \mathrm{M}$ it induces apoptosis in HT29 cells with a concentration-dependent mechanism involving the Akt/CSN6/Myc signaling axis (93) and at $200 \mu \mathrm{M}$ exhibits pro-apoptotic effects on Caco-2 and SW620 cell lines via nuclear factor kappa-B (NF-kB) signaling pathway inhibition and $\mathrm{BCl}-2$ and $\mathrm{Bax}$ modulation (94). In the same cell line (Caco-2), quercetin (20- $100 \mu \mathrm{M}$ ) has been found to induce apoptosis through the modulation of the apoptotic extrinsic pathway (95) and reduce topoisomerase II-induced DNA cleavage (96). An intriguing result is the demonstration that nutritionally relevant concentrations of quercetin (0.1 or $1 \mu \mathrm{M})$ mimicked the $17 \beta$-estradiol-induced apoptotic effect in ERß1-containing DLD1 colon cancer cell line and activated p38, which leads to caspase- 3 activation and PARP cleavage (97).

Quercetin (0.1-100 $\mu \mathrm{M})$ may also alter the metabolism of actively proliferating cells through the significant decrease in ornithine decarbox- ylase activity and polyamines biosynthesis observed in human DLD-1 colon cancer cell (98). Recent studies suggest that quercetin may increase the cytotoxic effect of standard antitumoral drugs also in CRC cells. In particular, quercetin $(33 \mu \mathrm{M})$ increased doxorubicin accumulation and enhanced the cytotoxic effect of doxorubicin on P-gp-overexpressing SW620/ Ad300 cells (99). Similar results were recorded on HT-29 cells, where quercetin $(50 \mu \mathrm{M})$ enhanced cisplatin-induced apoptosis. The effect was partially due to the inhibition of the activation of NF-KB expression (100).

Quercetin also exerts antiangiogenic effects in colorectal cancer cells. Since DLD-1 colon cancer cells have been found to release angiogenic factors, Xiao et al. co-cultured these cells with HUVECs. At 100 and $200 \mu \mathrm{M}$, quercetin significantly reduced endothelial tube formation (101).

Several murine and rat models have been used to investigate quercetin effects in CRC. Shree et al. tested the chemopreventive effect of quercetin ( 25 or $50 \mathrm{mg} / \mathrm{kg}$ bodyweight) on 1,2 dimethyl hydrazine (DMH)-induced rat coIon cancer. Quercetin significantly improved $\mathrm{DMH}$-induced pathological modifications. In particular, it reduced proliferation and colon cancer early markers (mucin depletion and goblet cell disintegration), adenomatous polyposis coli and $\beta$-catenin, and tumor incidence and multiplicity (102). Similar results were recorded on $\mathrm{N}$-methyl nitrosourea-induced rat colon cancer, where quercetin $(50 \mathrm{mg} / \mathrm{kg})$ blocked the overexpression of Wnt5a and up-regulated the expression of Axin-1, and decreased the serum level of TAG72 and GAL3 in colon cancer bearing rats (103).

Quercetin suppressed colon carcinogenesis also on mouse colon carcinogenesis induced by azoxymethane/dextran sodium sulfate. Quercetin $(30 \mathrm{mg} / \mathrm{kg})$ significantly decreased multiplicity and size of colon tumors and expression of oxidative stress and inflammation markers (104).

A recent study suggested that 3,4-dihydroxyphenylacetic acid (0.05-200 $\mu \mathrm{M})$, an antioxi- 
dant microbiota-derived metabolite of quercetin, protects against neoplastic mouse colonic transformation induced by hemin, a metabolite of myoglobin (105). In particular, the metabolite prevented the reduction of apoptosis, the increase in ROS levels and nucleic acids' oxidation, and the decrease in the mitochondrial membrane potential caused by hemin exposure.

Overall, quercetin exerts chemotherapeutic and chemopreventive effects in colorectal cancer models, which have been demonstrated to be mediated through various mechanisms, including cell-cycle arrest, increase in apoptosis, antioxidant properties, regulation of signaling pathways involved in CRC development, inhibition of angiogenesis. Taking into account that quercetin is present in many commonly food items, its beneficial effects on CRC are of promise in the light of the well-established relationship between dietary habits and CRC risk.

\section{Bladder cancer}

The first study on quercetin and bladder cancer $(B C)$ cell lines was carried out by $\mathrm{Ma}$ et al. (2006): quercetin 150 and $200 \mu \mathrm{M}$ inhibited cell growth, induced apoptosis, and arrested cell cycle in G0/G1 phase $(100 \mu \mathrm{M})(106)$. An antiproliferative effect of quercetin was also observed in human and murine BC cell lines (MB49, T24, UMUC3, 253J) via the activation of AMPK signaling $\left(\mathrm{IC}_{50}: 40-60 \mu \mathrm{M}\right)(107)$, but also via other mechanisms such as alterations in the extracellular catabolism of nucleotides (108) or activation of $K$ channels (109). Besides, quercetin $100 \mu \mathrm{M}$ downregulated MCT1 activity and promoted apoptosis in endothelial and T24 BC cells co-culture (110). Chen et al. reported that isoquercitrin (quercetin-3-O-glucoside) (ISO) $400 \mu \mathrm{M}$ inhibited BC cells proliferation and promoted apoptosis via suppression of PI3K/Akt survival signaling pathway (111). Its antiproliferative effect was also demonstrated in T24 cells where $20-80 \mu \mathrm{M}$ of ISO caused ROS overproduction and activation of the AMPK signaling pathway (112). ISO orally administered (doses were not indicated) inhib- ited BC growth also in nude mice (111). Other studies explored the use of quercetin in association with anticancer therapies with the aim of overcoming multiple drug resistance (MDR) phenotype (113). Quercetin (250 and $500 \mu \mathrm{M}$ ) plus gemcitabine $10 \mu \mathrm{M}$ decreased the expression of proteins involved in MDR including the $A B C C 2$ compared to the administration of the individual molecules alone (113). Moreover, quercetin plus cisplatin (both at $50 \mu \mathrm{M}$ ) synergistically reduced T24 and UMUC cell viability (114). A recent study documented that a quercetin-zinc complex $\geq 12.5 \mu \mathrm{M}$ decreased viability, cell migration and invasiveness and increased apoptosis in BC cells, with a mechanism involving down-regulation of pAkt/Akt and MT1-MMP protein expression (115). In addition, quercetin incorporated in sodium or zinc titanate nanotubes (both at 25-200 $\mu \mathrm{g} /$ $\mathrm{mL}$ ) decreased viability of $B C$ cells and their ability to form clones, thus suggesting that these nanostructures can interfere with cancer cell proliferation (116).

\section{CONCLUSIONS}

Many in vitro and in vivo studies were performed on quercetin, which documented its ability of inducing anticancer effects on different tumors and through different mechanisms (figure 5) and its great potential in the oncological field. However, quercetin undergoes a complex metabolism, transport, and distribution, which may not allow to reach adequate concentrations for pharmacological effects in target tissues. Thus, appropriate plasma concentrations in a similar high range such as those used on in vitro preclinical models could be not achieved for quercetin and many of its anticancer activities recorded in vitro may not be attainable in vivo. Nanoformulation-based approaches including liposomes, microemulsion, nanoparticles, and solid lipid nanoparticles have been developed with improved bioavailability and biologic features such as biphasic, inotropic and lusitropic characteristics. As an example, the encapsulation of querce- 


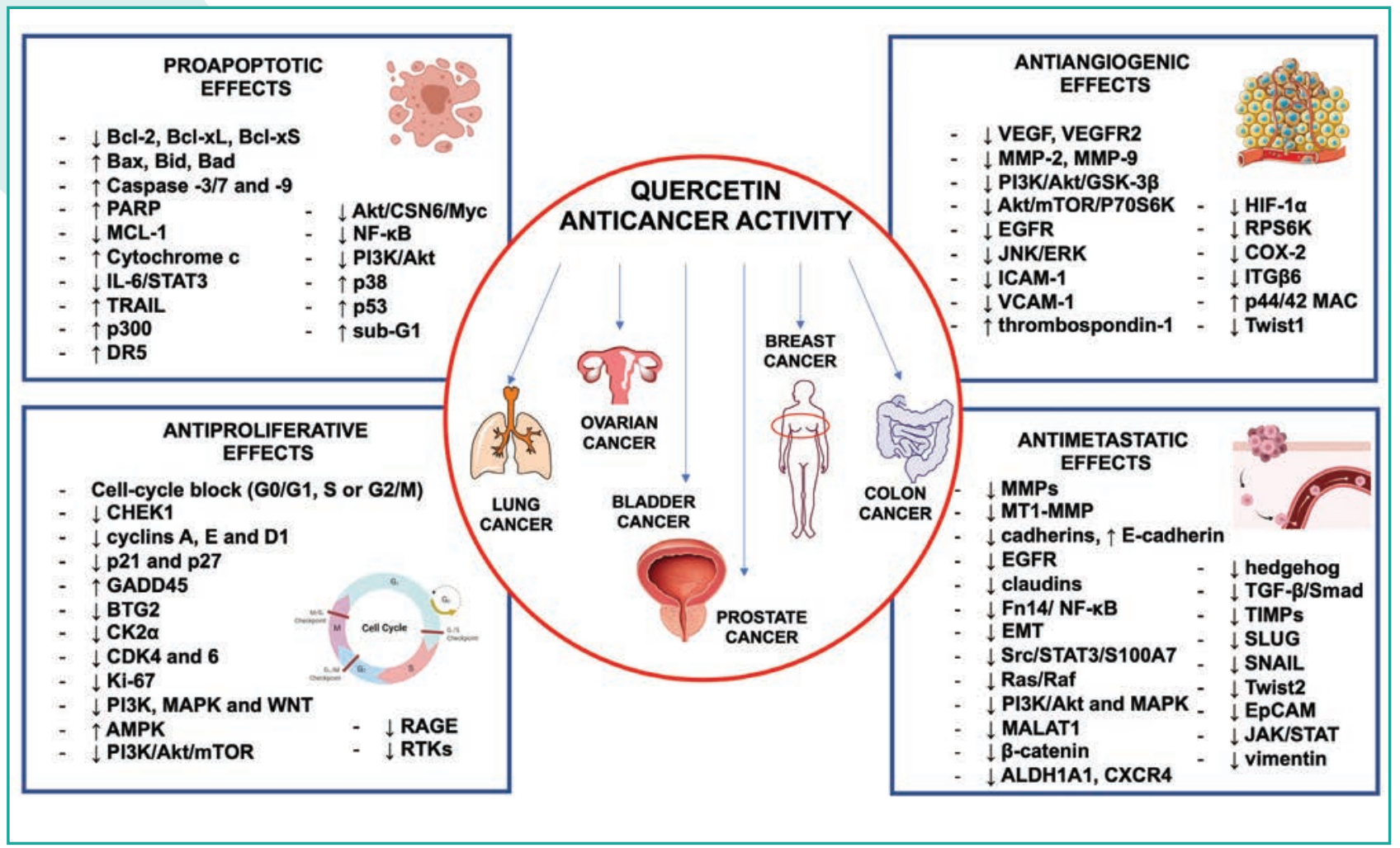

Figure 5. Schematic representation of the main molecular targets of quercetin.

$\uparrow$ : increase activity/expression; $\downarrow$ : decrease activity/expression; ALDH1A1: aldehyde dehydrogenase 1 family member A1; Akt: protein kinase B; AMPK: AMP-activated protein kinase; Bax: BCl-2-associated X protein; BCl-2: B-cell lymphoma 2; BCl-xL: B-cell lymphoma-extralarge; BCl-xS: $\mathrm{BCl}-\mathrm{x}$ short; $\mathrm{Bad}$ : $\mathrm{BCl}-2$ associated agonist of cell death; Bid: $\mathrm{BH} 3$ interacting-domain death agonist; CDK2: cyclin-dependent kinase 2; CDK4: cyclin-dependent kinase 4; CDK6: cyclin-dependent kinase 6; CHEK1: checkpoint kinase-1; CK2 $\alpha$ : casein kinase-2 $\alpha$; COX-2: cyclooxygenase-2; CSN6: constitutive photomorphogenesis 9 signalosome 6; CXCR4: C-X-C motif chemokine receptor 4; DR: death receptor; EGFR: epidermal growth factor receptor; EMT: epithelial-mesenchymal transition; EpCAM: epithelial cell adhesion molecule; ERK: extracellular signal-regulated protein kinase; Fn14: fibroblast growth factor-inducible protein 14; GADD45: growth arrest and DNA damage-inducible 45 protein; GSK3ß: glycogen synthase kinase 3 beta; HIF-1 $\alpha$ : hypoxia inducible factor-1 $\alpha$; ICAM-1: intracellular adhesion molecule-1; IL-6: interleukin-6; ITGB6: integrin 36 ; JAK: Janus kinase; JNK: c-Jun N-terminal kinases; MALAT1: metastasis-associated lung adenocarcinoma transcript 1; MAPK: mitogen-activated protein kinase; MCL-1: Myeloid Cell Leukemia 1; MMP: metalloproteinase; MT1-MMP: membrane type-1 matrix metalloproteinase; mTOR: mammalian target of rapamycin; NF-kB: nuclear factor kappa-light-chain-enhancer of activated B cells; p53: tumor protein p53; p21: cyclin-dependent kinase inhibitor 1A; PARP: poly (ADP-ribose) polymerase; PI3K: phosphatidylinositol 3-kinase; RAGE: receptor for advanced glycation end products; RPS6K: ribosomal protein S6 kinase; RTKs: receptor tyrosine kinases; P70S6K: phosphoprotein 70 ribosomal protein S6 kinase; S100 calcium binding protein A7; STAT3: signal transducer and activator of transcription 3; TGF: tumor growth factor; TIMPs: tissue inhibitors of metalloproteinases; TRAIL: tumor necrosis factor (TNF)-related apoptosis-inducing ligand; Twist: twist homolog; VCAM-1: vascular cell adhesion molecule 1; VEGF: vascular endothelial growth factor; VEGFR2: vascular endothelial growth factor receptor 2

tin into biodegradable monomethoxy poly (ethylene glycol)-poly(e-caprolactone) micelles improved the dispersion in water of quercetin and its in vivo anticancer activity (56). Similar results have been observed with PEGylated liposomal quercetin, which provided a sustained release of quercetin and resulted in an efficient formulation for in vivo tumor growth inhibition (72).

A crucial aspect in the oncological field is the identification of compounds able to selective- ly exert their effects on tumor cells without damaging healthy cells. What emerges from the few studies on normal human cells (lung embryonic fibroblasts, umbilical vein endothelial cells, peripheral blood lymphocytes) is that quercetin is able to block proliferation or induce apoptosis on cancer cells at concentrations $(<50 \mu \mathrm{M})$ exerting no or little effects on healthy cells (117).

However, the safety profile of quercetin is not yet fully understood. Based on its polyphenol 
structure with high number of hydroxyl groups and pi orbitals, quercetin is associated in first instance with antioxidant properties. Taking into account the presence of a hydroxyl group in position 3 that is subject to tautomerism and two hydroxyl groups on the $\mathrm{C}$-ring that are subject to oxidation, quercetin can also lead to the formation of highly reactive quinones. Quinones can react with thiols potentially causing DNA and protein damage (118). Antioxidant and pro-oxidant effects of quercetin depends on its cellular concentrations and on the cellular levels of reduced GSH: low concentrations of quercetin increase the antioxidant capacity of cells; higher concentrations of quercetin reduce antioxidant capacity and GSH content leading to cellular damage (119). With particular regard to dietary supplementation, human intervention studies did not report pro-oxidative effects of quercetin at doses of 500-1000 $\mathrm{mg} /$ day (i.e., a high daily supplementation) administered up to 12 weeks, but it is still unclear whether quercetin could evoke pro-oxidative effects in humans after a long-term use (120). Similarly, chronic toxicity animal studies evidenced potential nephrotoxic effects for quercetin, but human intervention studies rarely recorded adverse effects following supplemental quercetin intake, but no safety data are available after long-term use ( $>12$ weeks) of high quercetin doses ( $\geq 1000 \mathrm{mg}$ ) (120).

Based on in vitro studies, some additional critical safety aspects emerged for quercetin. Quercetin emerged as a mutagenic and po-

\section{REFERENCES}

1. Soerjomataram I, Bray F. Planning for tomorrow: global cancer incidence and the role of prevention 2020-2070. Nat Rev Clin Oncol 2021. Epub ahead of print.

2. Wach A, Pyrzyńska K, Biesaga M. Quercetin content in some food and herbal samples. Food Chem 2007;100(2):699-704.

3. Materska M. Quercetin and its derivatives: chemical structure and bioactivity- a review. Pol J Food Nutr Sci 58(4):407-13. tentially carcinogenic compound in the Ames test, but long-term animal toxicity studies did not confirm its carcinogenic potential (121). These controversial results could be due to the high non-physiological concentrations used in the in vitro studies, which are often performed at high concentrations of quercetin, ranging from $25 \mu \mathrm{M}$ to $200 \mu \mathrm{M}$, and do not take into account the complex pharmacokinetic profile of quercetin.

All in all, quercetin is a well-studied compound with a broad range of biologic advantages. A peculiar characteristic of quercetin is its ability to interact with multiple cellular targets and modulate the activity of several signaling pathways. Taking into account that they include key proteins within the same signaling network, quercetin may act with a pleiotropic, multilevel and synergistic mechanism of action. Thus, quercetin's broad target profile may represent a useful therapeutic strategy to tackle one of the most complex dynamic human diseases like cancer. Further in vivo studies and sound clinical trials are required to definitely assess its safety and efficacy and grant a fully understanding of quercetin's therapeutic potential both alone and in combination with standard anticancer chemotherapy.

\section{CONFLICT OF INTERESTS}

The authors declare that they have no conflict of interests.

4. Vafadar A, Shabaninejad Z, Movahedpour $A$, et al. Quercetin and cancer: new insights into its therapeutic effects on ovarian cancer cells. Cell Biosci 2020;10(1):32.

5. Treml J, Šmejkal K. Flavonoids as potent scavengers of hydroxyl radicals. Compr Rev Food Sci Food Saf 2016;15(4):720-38.

6. Guo Y, Mah E, Davis CG, et al. Dietary fat increases quercetin bioavailability in 
overweight adults. Mol Nutr Food Res 2013;57(5):896-905.

7. Batiha GE-S, Beshbishy AM, Ikram M, et al. The pharmacological activity, biochemical properties, and pharmacokinetics of the major natural polyphenolic flavonoid: quercetin. Foods 2020;9(3):E374.

8. Shabbir U, Rubab M, Daliri EB-M, Chelliah R, Javed A, Oh D-H. Curcumin, quercetin, catechins and metabolic diseases: the role of gut microbiota. Nutrients 2021;13(1):206.

9. Tang S-M, Deng X-T, Zhou J, Li Q-P, Ge $X-X$, Miao L. Pharmacological basis and new insights of quercetin action in respect to its anticancer effects. Biomed Pharmacother 2020;121:109604.

10. Hisaka T, Sakai H, Sato T, et al. Quercetin suppresses proliferation of liver cancer cell lines in vitro. Anticancer Res 2020;40(8):4695-700.

11. Jeon J-S, Kwon S, Ban K, et al. Regulation of the intracellular ROS Level is critical for the antiproliferative effect of quercetin in the hepatocellular carcinoma cell line HepG2. Nutr Cancer 2019;71(5):861-9.

12. Salama YA, El-Karef A, El Gayyar AM, Abdel-Rahman N. Beyond its antioxidant properties: quercetin targets multiple signalling pathways in hepatocellular carcinoma in rats. Life Sci 2019;236:116933.

13. Kedhari Sundaram M, Raina R, Afroze N, et al. Quercetin modulates signaling pathways and induces apoptosis in cervical cancer cells. Biosci Rep 2019;39(8):BSR20190720.

14. Lan C-Y, Chen S-Y, Kuo C-W, Lu C-C, Yen G-C. Quercetin facilitates cell death and chemosensitivity through RAGE/PI3K/AKT/ mTOR axis in human pancreatic cancer cells. J Food Drug Anal 2019;27(4):887-96.

15. Zhang $X$, Huang J, Yu C, et al. Quercetin Enhanced Paclitaxel Therapeutic Effects Towards PC-3 Prostate Cancer Through ER Stress Induction and ROS Production. Onco Targets Ther 2020;13:513-23.

16. Soll F, Ternent C, Berry IM, Kumari D, Moore TC. Quercetin inhibits proliferation and induces apoptosis of B16 melanoma cells in vitro. Assay Drug Dev Technol 2020;18(6):261-8.

17. Galluzzi L, Vitale I, Aaronson SA, et al. Molecular mechanisms of cell death: recommendations of the Nomenclature Committee on Cell Death 2018. Cell Death Differ 2018;25(3):486-541.

18. Rauf A, Imran $M$, Khan IA, et al. Anticancer potential of quercetin: a comprehensive review: quercetin as an anticancer agent. Phytother Res 2018;32(11):2109-30.

19. Almatroodi SA, Alsahli MA, Almatroudi A, et al. Potential therapeutic targets of quercetin, a plant flavonol, and its role in the therapy of various types of cancer through the modulation of various cell signaling pathways. Molecules 2021;26(5):1315.

20. Benvenuto M, Albonici L, Focaccetti C, et al. Polyphenol-mediated autophagy in cancer: evidence of in vitro and in vivo studies. Int J Mol Sci;21(18):6635.

21. Guo $H$, Ding $H$, Tang $X$, et al. Quercetin induces pro-apoptotic autophagy via SIRT1/AMPK signaling pathway in human lung cancer cell lines A549 and H1299 in vitro. Thorac Cancer 2021;12(9):1415-22.

22. Wang Z, Ma J, Li X, et al. Quercetin induces p53-independent cancer cell death through lysosome activation by the transcription factor $E B$ and reactive oxygen species-dependent ferroptosis. Br J Pharmacol 2021;178(5):1133-48.

23. Latunde-Dada GO. Ferroptosis: role of lipid peroxidation, iron and ferritinophagy. Biochim Biophys Acta 2017;1861(8):1893-900.

24. Khorsandi L, Orazizadeh M, Niazvand F, Abbaspour MR, Mansouri E, Khodadadi A. Quercetin induces apoptosis and necroptosis in MCF-7 breast cancer cells. BRATISL MED J 2017;118(02):123-8.

25. De Souza R, Costa Ayub L, Yip K. Mitotic catastrophe. In: Radosevich J, editor. Apoptosis and Beyond. Hoboken, NJ, USA: John Wiley \& Sons, Inc.; 2018. p. 475-510. Available at: http://doi.wiley. com/10.1002/9781119432463.ch23 
26. Klimaszewska-Wiśniewska A, HałasWiśniewska M, Izdebska M, Gagat M, Grzanka A, Grzanka D. Antiproliferative and antimetastatic action of quercetin on A549 non-small cell lung cancer cells through its effect on the cytoskeleton. Acta Histochem 2017;119(2):99-112.

27. Stuelten CH, Parent CA, Montell DJ. Cell motility in cancer invasion and metastasis: insights from simple model organisms. Nat Rev Cancer 2018;18(5):296-312.

28. Dong Y, Yang J, Yang L, Li P. Quercetin inhibits the proliferation and metastasis of human non-small cell lung cancer cell line: the key role of Src-mediated fibroblast growth factor-inducible 14 (Fn14)/ nuclear factor kappa B (NF-kB) pathway. Med Sci Monit 2020;26(e920537).

29. Guo Y, Tong Y, Zhu H, et al. Quercetin suppresses pancreatic ductal adenocarcinoma progression via inhibition of $\mathrm{SHH}$ and TGF- $\beta /$ Smad signaling pathways. Cell Biol Toxicol 2021;37(3):479-96.

30. Fan J-J, Hsu W-H, Lee K-H, et al. Dietary flavonoids luteolin and quercetin inhibit migration and invasion of squamous carcinoma through reduction of $\mathrm{Src} / \mathrm{Stat} 3 / \mathrm{S} 100 \mathrm{~A} 7$ signaling. Antioxidants 2019;8(11):557.

31. Kim SR, Lee EY, Kim DJ, Kim HJ, Park HR. Quercetin inhibits cell survival and metastatic ability via the EMT-mediated pathway in oral squamous cell carcinoma. Molecules 2020;25(3):757.

32. Zhao J, Fang Z, Zha Z, et al. Quercetin inhibits cell viability, migration and invasion by regulating miR-16/HOXA10 axis in oral cancer. Eur $\mathrm{J}$ Pharmacol 2019;847:11-8.

33. Li S, Pei Y, Wang W, Liu F, Zheng K, Zhang $X$. Quercetin suppresses the proliferation and metastasis of metastatic osteosarcoma cells by inhibiting parathyroid hormone receptor 1 . Biomed Pharmacother 2019;114:108839.

34. Xu Z, Zhao D, Zheng X, Huang B, Xia X, Pan $X$. Quercetin exerts bidirectional regulation effects on the efficacy of tamoxifen in estrogen receptor-positive breast cancer therapy: An in vitro study. Environ Toxicol 2020;35(11):1179-93.

35. Dhanaraj T, Mohan M, Arunakaran J. Quercetin attenuates metastatic ability of human metastatic ovarian cancer cells via modulating multiple signaling molecules involved in cell survival, proliferation, migration and adhesion. Arch Biochem Biophys 2021;701:108795.

36. Shahi Thakuri P, Gupta M, Singh S, et al. Phytochemicals inhibit migration of triple negative breast cancer cells by targeting kinase signaling. BMC Cancer 2020;20(1):4.

37. Wu L, Li J, Liu T, et al. Quercetin shows anti-tumor effect in hepatocellular carcinoma LM3 cells by abrogating JAK2/ STAT3 signaling pathway. Cancer Med 2019;8(10):4806-20.

38. Lu X, Chen D, Yang F, Xing N. Quercetin inhibits epithelial-to-mesenchymal transition (EMT) process and promotes apoptosis in prostate cancer via downregulating IncRNA MALAT1. Cancer Manag Res 2020;12:1741-50.

39. Ghazi T, Arumugam T, Foolchand A, Chuturgoon AA. The impact of natural dietary compounds and food-borne mycotoxins on DNA methylation and cancer. Cells 2020;9(9):E2004.

40. Alvarez MC, Maso V, Torello CO, Ferro KP, Saad STO. The polyphenol quercetin induces cell death in leukemia by targeting epigenetic regulators of pro-apoptotic genes. Clin Epigenet 2018;10(1):139.

41. Abbaszadeh S, Rashidipour M, Khosravi P, Shahryarhesami S, Ashrafi B, Kaviani M, et al. Biocompatibility, cytotoxicity, antimicrobial and epigenetic effects of novel chitosan-based quercetin nanohydrogel in human cancer cells. Int J Nanomedicine 2020;15:5963-75.

42. Biswas S, Reddy ND, Jayashree BS, Rao CM. Evaluation of novel 3-Hydroxyflavone analogues as HDAC inhibitors against colorectal cancer. Adv Pharmacol Sci 2018;2018:4751806. 
43. Saghafi, Taheri, Parkkila, Emameh. Phytochemicals as modulators of iong non-coding RNAs and inhibitors of cancer-related carbonic anhydrases. Int J Mol Sci 2019;20(12):2939.

44. Ma T, Liu Y, Wu Q, et al. Quercetin-modified metal-organic frameworks for dual sensitization of radiotherapy in tumor tissues by inhibiting the carbonic anhydrase IX. ACS Nano 2019;13(4):4209-19.

45. Cione E, La Torre C, Cannataro R, Caroleo MC, Plastina P, Gallelli L. Quercetin, epigallocatechin gallate, curcumin, and resveratrol: from dietary sources to human microRNA modulation. Molecules 2019;25(1):63.

46. Pham TND, Stempel S, Shields MA, et al. Quercetin enhances the anti-tumor effects of BET inhibitors by suppressing hnRNPA1. Int J Mol Sci 2019;20(17):4293.

47. Kedhari Sundaram M, Hussain A, Haque $S$, Raina R, Afroze N. Quercetin modifies 5 'CpG promoter methylation and reactivates various tumor suppressor genes by modulating epigenetic marks in human cervical cancer cells. J Cell Biochem 2019;120(10):18357-69.

48. Hanahan D, Weinberg RA. Hallmarks of Cancer: The Next Generation. Cell 2011;144(5):646-74.

49. Wong MLH, Prawira A, Kaye AH, Hovens $\mathrm{CM}$. Tumour angiogenesis: its mechanism and therapeutic implications in malignant gliomas. J Clin Neurosci 2009;16(9):1119-30.

50. Pratheeshkumar P, Budhraja A, Son Y-O, et al. Quercetin inhibits angiogenesis mediated human prostate tumor growth by targeting VEGFR- 2 regulated AKT/mTOR/ P70S6K signaling pathways. Gautam S, editor. PLoS ONE 2012;7(10):e47516.

51. Balakrishnan S, Bhat FA, Raja Singh $P$, et al. Gold nanoparticle-conjugated quercetin inhibits epithelial-mesenchymal transition, angiogenesis and invasiveness via EGFR/ VEGFR-2-mediated pathway in breast cancer. Cell Prolif 2016;49(6):678-97.
52. Lupo G, Cambria MT, Olivieri M, et al. Anti-angiogenic effect of quercetin and its 8-methyl pentamethyl ether derivative in human microvascular endothelial cells. J Cell Mol Med 2019;23(10):6565-77.

53. Wang L, Wu H, Xiong $L$, et al. Quercetin downregulates cyclooxygenase-2 expression and HIF-1 $\alpha /$ VEGF signaling-related angiogenesis in a mouse model of abdominal aortic aneurysm. Biomed Res Int 2020;2020:9485398.

54. Lei C-S, Hou Y-C, Pai M-H, Lin M-T, Yeh S-L. Effects of quercetin combined with anticancer drugs on metastasis-associated factors of gastric cancer cells: in vitro and in vivo studies. J Nutr Biochem 2018;51:105-13.

55. Liu Y, Tang Z-G, Yang J-Q, et al. Low concentration of quercetin antagonizes the invasion and angiogenesis of human glioblastoma U251 cells. Onco Targets Ther 2017;10:4023-8.

56. Gao X, Wang B, Wei X, et al. Anticancer effect and mechanism of polymer micelle-encapsulated quercetin on ovarian cancer. Nanoscale 2012;4(22):7021.

57. Kashyap D, Garg VK, Tuli HS, et al. Fisetin and quercetin: promising flavonoids with chemopreventive potential. Biomolecules. 2019;9(5):174.

58. Kasiri N, Rahmati M, Ahmadi L, Eskandari $\mathrm{N}$, Motedayyen $\mathrm{H}$. Therapeutic potential of quercetin on human breast cancer in different dimensions. Inflammopharmacol 2020;28(1):39-62.

59. Umar SM, Kashyap A, Kahol S, et al. Prognostic and therapeutic relevance of phosphofructokinase platelet-type (PFKP) in breast cancer. Exp Cell Res 2020;396(1):112282.

60. Jia L, Huang S, Yin X, Zan Y, Guo Y, Han L. Quercetin suppresses the mobility of breast cancer by suppressing glycolysis through Akt-mTOR pathway mediated autophagy induction. Life Sci 2018;208:123-30.

61. Wang R, Yang L, Li S, et al. Quercetin inhibits breast cancer stem cells via downregulation of aldehyde dehydrogenase 
1A1 (ALDH1A1), chemokine receptor Type 4 (CXCR4), mucin 1 (MUC1), and epithelial cell adhesion molecule (EpCAM). Med Sci Monit 2018;24:412-20.

62. D'Arrigo G, Gianquinto E, Rossetti G, Cruciani G, Lorenzetti S, Spyrakis F. Binding of androgen- and estrogen-like flavonoids to their cognate (non)nuclear receptors: a comparison by computational prediction. Molecules 2021;26(6):1613.

63. Peiffer DS, Ma E, Wyatt D, Albain KS, Osipo C. DAXX-inducing phytoestrogens inhibit ER+ tumor initiating cells and delay tumor development. npj Breast Cancer 2020;6(1):37.

64. Yousuf $M$, Khan $P$, Shamsi $A$, et al. Inhibiting CDK6 activity by quercetin is an attractive strategy for cancer therapy. ACS Omega 2020;5(42):27480-91.

65. Cheng H-W, Chiang C-S, Ho H-Y, et al. Dextran-modified Quercetin-Cu(II)/hyaluronic acid nanomedicine with natural poly(ADP-ribose) polymerase inhibitor and dual targeting for programmed synthetic lethal therapy in triple-negative breast cancer. J Control Release 2021;329:136-47.

66. Danics L, Schvarcz CA, Viana P, et al. Exhaustion of protective heat shock response induces significant tumor damage by apoptosis after modulated electro-hyperthermia treatment of triple negative breast cancer isografts in mice. Cancers 2020;12(9):2581.

67. Liu M, Fu M, Yang $X$, et al. Paclitaxel and quercetin co-loaded functional mesoporous silica nanoparticles overcoming multidrug resistance in breast cancer. Colloids Surf B Biointerfaces 2020;196:111284.

68. Patel G, Thakur NS, Kushwah V, et al. Liposomal delivery of mycophenolic acid with quercetin for improved breast cancer therapy in SD rats. Front Bioeng Biotechnol 2020;8:631.

69. Catanzaro D, Ragazzi E, Vianello C, Caparrotta L, Montopoli M. Effect of quercetin on cell cycle and cyclin expression in ovarian carcinoma and osteosarcoma cell lines. Nat Prod Commun 2015;10(8):1365-8.
70. Liu Y, Gong W, Yang ZY, et al. Quercetin induces protective autophagy and apoptosis through ER stress via the p-STAT3/ Bcl-2 axis in ovarian cancer. Apoptosis 2017;22(4):544-57.

71. Teekaraman D, Elayapillai SP, Viswanathan MP, Jagadeesan A. Quercetin inhibits human metastatic ovarian cancer cell growth and modulates components of the intrinsic apoptotic pathway in PA-1 cell line. Chem Biol Interact 2019;300:91-100.

72. Long $Q$, Xie $Y$, Huang $Y$, et al. Induction of apoptosis and inhibition of angiogenesis by PEGylated liposomal quercetin in both cisplatin-sensitive and cisplatin-resistant ovarian cancers. J Biomed Nanotechnol 2013;9(6):965-75.

73. Lee D-H, Szczepanski M, Lee YJ. Role of Bax in quercetin-induced apoptosis in human prostate cancer cells. Biochem Pharmacol 2008;75(12):2345-55.

74. Aalinkeel R, Bindukumar B, Reynolds JL, et al. The dietary bioflavonoid, quercetin, selectively induces apoptosis of prostate cancer cells by down-regulating the expression of heat shock protein 90 . Prostate 2008;68(16):1773-89.

75. Senthilkumar K, Elumalai $P$, Arunkumar $\mathrm{R}$, et al. Quercetin regulates insulin like growth factor signaling and induces intrinsic and extrinsic pathway mediated apoptosis in androgen independent prostate cancer cells (PC-3). Mol Cell Biochem 2010;344(1-2):173-84.

76. Yang $F$, Jiang $X$, Song $L$, et al. Quercetin inhibits angiogenesis through thrombospondin-1 upregulation to antagonize human prostate cancer PC-3 cell growth in vitro and in vivo. Oncology Reports 2016;35(3):1602-10.

77. Yang $F$, Song $L$, Wang $H$, Wang J, Xu Z, Xing $N$. Combination of Quercetin and 2-Methoxyestradiol Enhances Inhibition of Human Prostate Cancer LNCaP and PC-3 Cells Xenograft Tumor Growth. PLoS One 2015;10(5):e0128277. 
78. Lu X, Yang F, Chen D, et al. Quercetin reverses docetaxel resistance in prostate cancer via androgen receptor and PI3K/ Akt signaling pathways. Int $\mathrm{J}$ Biol Sci 2020;16(7):1121-34.

79. McCann SE, Ambrosone CB, Moysich KB, et al. Intakes of Selected Nutrients, Foods, and Phytochemicals and Prostate Cancer Risk in Western New York. Nutr Cancer 2005;53(1):33-41.

80. Liu W, Du Y, Wen R, Yang M, Xu J. Drug resistance to targeted therapeutic strategies in non-small cell lung cancer. Pharmacol Ther 2020;206:107438.

81. Chuang $\mathrm{C}-\mathrm{H}$, Chan S-T, Chen C-H, Yeh S-L. Quercetin enhances the antitumor activity of trichostatin $A$ through up-regulation of p300 protein expression in p53 null cancer cells. Chem Biol Interact 2019;306:54-61.

82. Eisenberg-Lerner A, Bialik S, Simon H-U, Kimchi A. Life and death partners: apoptosis, autophagy and the cross-talk between them. Cell Death Differ 2009;16(7):966-75.

83. Hall A. The cytoskeleton and cancer. Cancer Metastasis Rev 2009;28(1-2):5-14.

84. Wang W, Liu F, Wang C, Wang C, Tang Y, Jiang $Z$. Src promotes metastasis of human non-small cell lung cancer cells through Fn14-mediated NF- $\mathrm{KB}$ signaling. Med Sci Monit 2018;24:1282-94.

85. Du Z, Lovly CM. Mechanisms of receptor tyrosine kinase activation in cancer. Mol Cancer 2018;17(1):58.

86. Baby B, Antony P, Vijayan R. Interactions of quercetin with receptor tyrosine kinases associated with human lung carcinoma. Nat Prod Res 2018;32(24):2928-31.

87. Li H, Zhang J, Xie Y. Elevated nuclear CDK6 is associated with an unfavorable prognosis in lung adenocarcinoma patients. Int J Clin Exp Pathol 2017;10(9):9614-20.

88. Liu K, Chen W, Yang T, et al. Paclitaxel and quercetin nanoparticles co-loaded in microspheres to prolong retention time for pulmonary drug delivery. Int J Nanomedicine 2017;12:8239-55.
89. Wang $Y$, Yu H, Wang S, et al. Targeted delivery of quercetin by nanoparticles based on chitosan sensitizing paclitaxel-resistant lung cancer cells to paclitaxel. Mater Sci Eng C 2021;119:111442.

90. Shen Y, TanTai J. Co-delivery anticancer drug nanoparticles for synergistic therapy against lung cancer cells. Drug Des Devel Ther 2020;14:4503-10.

91. Darband SG, Kaviani M, Yousefi B, et al. Quercetin: a functional dietary flavonoid with potential chemo-preventive properties in colorectal cancer. J Cell Physiol 2018;233(9):6544-60.

92. van Erk MJ, Roepman P, van der Lende $T R$, et al. Integrated assessment by multiple gene expression analysis of quercetin bioactivity on anticancer-related mechanisms in colon cancer cells in vitro. Eur $\mathrm{J}$ Nutr 2005;44(3):143-56.

93. Yang L, Liu Y, Wang $M$, et al. Quercetin-induced apoptosis of HT-29 colon cancer cells via inhibition of the Akt-CSN6-Myc signaling axis. Mol Med Rep 2016;14(5):4559-66.

94. Zhang X-A, Zhang S, Yin O, Zhang J. Quercetin induces human colon cancer cells apoptosis by inhibiting the nuclear factor-kappa B Pathway. Pharmacogn Mag 2015;11(42):404-9.

95. Psahoulia FH, Drosopoulos KG, Doubravska L, Andera L, Pintzas A. Quercetin enhances TRAIL-mediated apoptosis in colon cancer cells by inducing the accumulation of death receptors in lipid rafts. Mol Cancer Ther 2007;6(9):2591-9.

96. Cosan DT, Soyocak A, Basaran A, Degirmenci İ, Gunes HV, Mutlu Sahin F. Effects of various agents on DNA fragmentation and telomerase enzyme activities in adenocarcinoma cell lines. Mol Biol Rep 2011;38(4):2463-9.

97. Bulzomi P, Galluzzo P, Bolli A, Leone S, Acconcia $F$, Marino M. The pro-apoptotic effect of quercetin in cancer cell lines requires ER $\beta$-dependent signals. J Cell Physiol 2012;227(5):1891-8. 
98. Linsalata M, Orlando A, Messa C, Refolo MG, Russo F. Quercetin inhibits human DLD-1 colon cancer cell growth and polyamine biosynthesis. Anticancer Res 2010;30(9):3501-7.

99. Zhou Y, Zhang J, Wang K, et al. Quercetin overcomes colon cancer cells resistance to chemotherapy by inhibiting solute carrier family 1, member 5 transporter. Eur J Pharmacol 2020;881:173185.

100. Jin W, Han H, Ma L, Zhou H, Zhao C. The chemosensitization effect of quercetin on cisplatin induces the apoptosis of human colon cancer HT-29 cell line. Int J Clin Exp Med 2016;9(2):2285-92.

101. Xiao X, Shi D, Liu L, et al. Quercetin suppresses cyclooxygenase-2 expression and angiogenesis through inactivation of P300 signaling. PLoS ONE 2011;6(8):e22934.

102. Shree A, Islam J, Sultana S. Quercetin ameliorates reactive oxygen species generation, inflammation, mucus depletion, goblet disintegration, and tumor multiplicity in colon cancer: Probable role of adenomatous polyposis coli, $\beta$-catenin. Phytother Res 2021;35(4):2171-84.

103. Ahmed H, Aglan H, Zaazaa A, Shalby A, El-Toumy S. Quercetin confers tumoricidal activity through multipathway mechanisms in a N-methylnitrosourea rat model of colon cancer. Asian Pac J Cancer Prev 2016;17(11):4991-8.

104. Lin R, Piao M, Song Y, Liu C. Quercetin suppresses AOM/DSS-induced colon carcinogenesis through its anti-inflammation effects in mice. J Immunol Res 2020;2020:9242601.

105. Catalán M, Ferreira J, Carrasco-Pozo C. The microbiota-derived metabolite of quercetin, 3,4-dihydroxyphenylacetic acid prevents malignant transformation and mitochondrial dysfunction induced by hemin in colon cancer and normal colon epithelia cell lines. Molecules 2020;25(18):4138.

106. Ma L. Growth inhibitory effects of quercetin on bladder cancer cell. Front Biosci 2006;11(1):2275.
107. Su $Q$, Peng $M$, Zhang $Y$, et al. Quercetin induces bladder cancer cells apoptosis by activation of AMPK signaling pathway. Am J Cancer Res 2016;6(2):498-508.

108. Rockenbach L, Bavaresco L, Fernandes Farias $\mathrm{P}$, et al. Alterations in the extracellular catabolism of nucleotides are involved in the antiproliferative effect of quercetin in human bladder cancer T24 cells. Urol Oncol-Semin Ori 2013;31(7):1204-11.

109. Kim Y, Kim W-J, Cha E-J. Quercetin-induced growth inhibition in human bladder cancer cells Is associated with an increase in Ca-activated $\mathrm{K}$ channels. Korean J Physiol Pharmacol 2011;15(5):279-83.

110. Hu KY, Wang DG, Liu PF, et al. Targeting of MCT1 and PFKFB3 influences cell proliferation and apoptosis in bladder cancer by altering the tumor microenvironment. Oncol Rep 2016;36(2):945-51.

111. Chen F, Chen X, Yang D, et al. Isoquercitrin inhibits bladder cancer progression in vivo and in vitro by regulating the $\mathrm{PI} 3 \mathrm{~K} / \mathrm{Akt}$ and PKC signaling pathways. Oncol Rep 2016;36(1):165-72.

112. Wu P, Liu S, Su J, et al. Apoptosis triggered by isoquercitrin in bladder cancer cells by activating the AMPK-activated protein kinase pathway. Food Funct 2017;8(10):3707-22.

113. Cho C, Yu C, Wu C, Ho J, Yang C, Yu $D$. Decreased drug resistance of bladder cancer using phytochemicals treatment. Kaohsiung J Med Sci 2021;37(2):128-35.

114. Oršolić N, Odeh D, Jembrek MJ, Knežević $J$, Kučan D. Interactions between cisplatin and quercetin at physiological and hyperthermic conditions on cancer cells in vitro and in vivo. Molecules 2020;25(14):3271.

115. Lee Y-H, Tuyet P-T. Synthesis and biological evaluation of quercetin-zinc (II) complex for anti-cancer and anti-metastasis of human bladder cancer cells. In Vitro Cell Dev Biol Animal 2019;55(6):395-404.

116. Alban L, Monteiro WF, Diz FM, et al. New quercetin-coated titanate nanotubes and their radiosensitization effect on human 
bladder cancer. Mater Sci Eng C Mater Biol Appl 2020;110:110662.

117. Gibellini L, Pinti M, Nasi $M$, et al. Quercetin and cancer chemoprevention. Evid Based Complementary Altern Med 2011;2011:1-15.

118. Jain A, Madu CO, Lu Y. Phytochemicals in chemoprevention: a cost-effective complementary approach. J Cancer 2021;12(12):3686-700.

119. Robaszkiewicz A, Balcerczyk A, Bartosz G. Antioxidative and prooxidative effects of quercetin on A549 cells. Cell Biol Int 2007;31(10):1245-50.

120. Andres S, Pevny S, Ziegenhagen R, et al. Safety aspects of the use of quercetin as a dietary supplement. Mol Nutr Food Res 2018;62(1):1700447.

121. Kapešová J, Petrásková L, Markošová K, et al. Bioproduction of quercetin and rutinose catalyzed by rutinosidase: novel concept of "Solid state biocatalysis." Int J Mol Sci 2019;20(5):1112.

122. Varoni EM, Lo Faro AF, Sharifi-Rad J, Iriti M. Anticancer molecular mechanisms of resveratrol. Front Nutr. 2016;12;3:8.

123. de Vries JH, Hollman PC, Meyboom S, et al. Plasma concentrations and urinary excretion of the antioxidant flavonols quercetin and kaempferol as biomarkers for dietary intake. Am J Clin Nutr 1998;68(1):60-5.

124. de Vries JH, Hollman PC, van Amersfoort I, Olthof MR, Katan MB. Red wine is a poor source of bioavailable flavonols in men. J Nutr 2001;131(3):745-8.
125. Hollman PC, van Trijp JM, Buysman $\mathrm{MN}$, et al. Relative bioavailability of the antioxidant flavonoid quercetin from various foods in man. FEBS Lett 1997;418(1-2):152-6.

126. Graefe EU, Wittig J, Mueller S, et al. Pharmacokinetics and bioavailability of quercetin glycosides in humans. J Clin Pharmacol 2001;41(5):492-9.

127. Shi Y, Williamson G. Comparison of the urinary excretion of quercetin glycosides from red onion and aglycone from dietary supplements in healthy subjects: a randomized, single-blinded, cross-over study. Food Funct 2015;6(5):1443-8.

128. Olth of MR, Hollman PC, Vree TB, Ka$\tan$ MB. Bioavailabilities of quercetin-3-glucoside and quercetin-4'-glucoside do not differ in humans. J Nutr 2000;130(5):1200-3.

129. Hollman PC, Bijsman MN, van Gameren $Y$, Cnossen EP, de Vries JH, Katan MB. The sugar moiety is a major determinant of the absorption of dietary flavonoid glycosides in man. Free Radic Res 1999;31(6):569-73.

130. Moon YJ, Wang L, DiCenzo R, Morris ME. Quercetin pharmacokinetics in humans. Biopharm Drug Dispos 2008;29(4):205-17.

131. Mutlu Altundağ E, Yılmaz AM, Serdar BS, Jannuzzi AT, Koçtürk S, Yalçın AS. Synergistic induction of apoptosis by quercetin and curcumin in chronic myeloid leukemia (K562) cells: II. signal transduction pathways involved. Nutr Cancer 2021;73(4):703-12. 